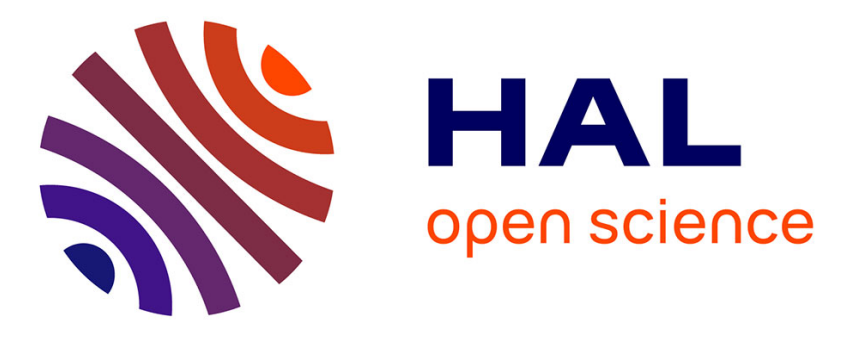

\title{
Early Hypoexcitability in a Subgroup of Spinal Motoneurons in Superoxide Dismutase 1 Transgenic Mice, a Model of Amyotrophic Lateral Sclerosis
} Anton Filipchuk, Arnaud Pambo-Pambo, Fanny Gaudel, Sylvie Liabeuf, Cécile Brocard, Jean Patrick Gueritaud, Jacques Durand

\section{To cite this version:}

Anton Filipchuk, Arnaud Pambo-Pambo, Fanny Gaudel, Sylvie Liabeuf, Cécile Brocard, et al.. Early Hypoexcitability in a Subgroup of Spinal Motoneurons in Superoxide Dismutase 1 Transgenic Mice, a Model of Amyotrophic Lateral Sclerosis. Neuroscience, 2021, 463, pp.337-353. 10.1016/j.neuroscience.2021.01.039 . hal-03223249

\author{
HAL Id: hal-03223249 \\ https://hal.science/hal-03223249
}

Submitted on 11 May 2021

HAL is a multi-disciplinary open access archive for the deposit and dissemination of scientific research documents, whether they are published or not. The documents may come from teaching and research institutions in France or abroad, or from public or private research centers.
L'archive ouverte pluridisciplinaire HAL, est destinée au dépôt et à la diffusion de documents scientifiques de niveau recherche, publiés ou non, émanant des établissements d'enseignement et de recherche français ou étrangers, des laboratoires publics ou privés. 


\title{
Early Hypoexcitability in a Subgroup of Spinal Motoneurons in Superoxide Dismutase 1 Transgenic Mice, a Model of Amyotrophic Lateral Sclerosis
}

\author{
Anton Filipchuk, ${ }^{a, b}$ Arnaud Pambo-Pambo, ${ }^{a}$ Fanny Gaudel, ${ }^{a}$ Sylvie Liabeuf, ${ }^{a}$ Cécile Brocard, ${ }^{a}$ Jean Patrick Gueritaud ${ }^{a}$ and \\ Jacques Durand ${ }^{\text {a* }}$ \\ a Institut de Neurosciences de la Timone, Equipe P3M, UMR 7289 CNRS-AMU, Aix Marseille Université, 27 Bd Jean Moulin, 13585 Marseille \\ Cedex 20, France \\ ${ }^{\mathrm{b}}$ Paris-Saclay Institute of Neuroscience (NeuroPSI), Department of Integrative and Computational Neuroscience (ICN), Centre National de la \\ Recherche Scientifique (CNRS), 91198 Gif-sur-Yvette, France
}

\begin{abstract}
In amyotrophic lateral sclerosis (ALS), large motoneurons degenerate first, causing muscle weakness. Transgenic mouse models with a mutation in the gene encoding the enzyme superoxide dismutase 1 (SOD1) revealed that motoneurons innervating the fast-fatigable muscular fibres disconnect very early. The cause of this peripheric disconnection has not yet been established. Early pathological signs were described in motoneurons during the postnatal period of SOD1 transgenic mice. Here, we investigated whether the early changes of electrical and morphological properties previously reported in the SOD1 ${ }^{\text {G85R }}$ strain also occur in the SOD1 ${ }^{\text {G93A-low }}$ expressor line with particular attention to the different subsets of motoneurons defined by their discharge firing pattern (transient, sustained, or delayed-onset firing). Intracellular staining and recording were performed in lumbar motoneurons from entire brainstem-spinal cord preparations of SOD1 ${ }^{\text {G93A-low }}$ transgenic mice and their WT littermates during the second postnatal week. Our results show that SOD ${ }^{\text {G93A-low }}$ motoneurons exhibit a dendritic overbranching similar to that described previously in the SOD ${ }^{\mathrm{G} 85 R}$ strain at the same age. Further we found an hypoexcitability in the delayed-onset firing SOD1 ${ }^{\text {G93A-low }}$ motoneurons (lower gain and higher voltage threshold). We conclude that dendritic overbranching and early hypoexcitability are common features of both low expressor SOD1 mutants (G85R and G93A-low). In the high-expressor SOD1 ${ }^{\text {G93A }}$ line, we found hyperexcitability in the sustained firing motoneurons at the same period, suggesting a delay in compensatory mechanisms. Overall, our results suggest that the hypoexcitability indicate an early dysfunction of the delayed-onset motoneurons and could account as early pathological signs of the disease. (c) 2021 IBRO. Published by Elsevier Ltd. All rights reserved.
\end{abstract}

Key words: ALS, spinal cord, dendritic overbranching, delayed-onset firing pattern.

\section{INTRODUCTION}

Amyotrophic lateral sclerosis (ALS) is a complex neurodegenerative disease that affects cortical neurons in the motor cortex as well as spinal and brainstem motoneurons, except for those innervating the extraocular and pelvic muscles (Kanning et al., 2010; Robberecht and Philips, 2013). The discovery of the superoxide dismutase 1 (SOD1) mutation responsible for ALS (Rosen et al., 1993) led to the genetic engineering of transgenic SOD1 mice (Gurney et al., 1994; Bruijn et al., 1997, 1998), which stand today as the standard animal model of ALS by mimicking most of the pathological mechanisms leading to motoneuron degeneration. A

\footnotetext{
${ }^{*}$ Corresponding author.

E-mail address: jacques.durand@univ-amu.fr (J. Durand).

Abbreviations: ALS, amyotrophic lateral sclerosis; FF, fast-fatigable; SOD1, superoxide dismutase 1
}

SOD1-dependent pathogenic mechanism, common to familial and sporadic ALS, has been identified as wildtype (WT) SOD1 acquired toxicity following protein oxidation and conformational changes (Bosco et al., 2010). The early pathological signs appearing before the onset of clinical symptoms include slowed axonal transport (Williamson and Cleveland, 1999), altered excitability (Pieri et al., 2003; Kuo et al., 2005; Bories et al., 2007; Van Zundert et al., 2008, 2012; Pambo-Pambo et al., 2009; Elbasiouny et al., 2010; Quinlan et al., 2011), denervation of axonal fibres (Pun et al., 2006; Hegedus et al., 2007; Saxena et al., 2009), neurofilament perturbations, mitochondrial alterations and glutamate excitotoxicity (Robberecht and Philips, 2013; Taylor et al., 2016). Unfortunately, no curative therapy is yet available, possibly due to late diagnosis (Robberecht and Philips, 2013). It has long been known that large spinal motoneurons are the first affected during the course of the disease (Kanning 
et al., 2010; Vucic et al., 2014; Taylor et al., 2016). Specifically, the fast-fatigable (FF) motoneurons disconnect in the SOD1 mouse model well before clinical symptoms (Pun et al., 2006; Hegedus et al., 2008; Saxena et al., 2009; Vinsant et al., 2013; Hadzipasic et al., 2014). However, the reasons for this peripheral nerve-muscle disjunction remain unknown.

We previously reported hypoexcitable lumbar motoneurons in SOD1 ${ }^{\mathrm{G} 85 \mathrm{R}}$ mice and dendritic overbranching occurring during the postnatal period (between postnatal days P3 and P8) (Durand et al., 2006; Amendola et al., 2007; Bories et al., 2007; Amendola and Durand, 2008; Filipchuk and Durand, 2012). Next, we addressed the cause of this abnormal dendritic growth in the SOD ${ }^{\mathrm{G} 85 \mathrm{R}}$ mice, and whether another strain of SOD1 mice (SOD1 ${ }^{\text {G93A-low })}$ develops such dendritic overbranching and hypoexcitability at the same period. In our previous investigations in postnatal SOD1 mice, we found that the spinal networks involved in locomotor function were not responsive to conventional pharmacological agents (Amendola et al., 2004; Durand et al., 2006), and hypothesized that a delay descending pathways arrival could explain this dysfunction (Amendola et al., 2004; Durand et al., 2006). Such a delay would imply a reduced number of presynaptic afferents to motoneurons. In the present study we performed immunohistochemistry for synaptophysin in order to determine whether terminal boutons are missing in the region of motoneuronal pools in $\mathrm{SOD} 1^{\mathrm{G} 85 \mathrm{R}}$ mice.

Dendritic overbranching, intracellular recordings and neurobiotin staining allowed us to identify and compare the morphologies of lumbar motoneurons in SOD $1^{\text {G93A- }}$ low mice and their WT littermates. Recently, we classified lumbar motoneurons in postnatal mice into three subgroups according to their firing patterns (transient, sustained, and delayed-onset firing) (Durand et al., 2015). Transient motoneurons fire one or a few spikes during a long current pulse and disappear with maturation (Vinay et al., 2000; Mentis et al., 2007; Durand et al., 2015), whereas delayed-onset firing motoneurons exhibit a late spiking and display the highest rheobase compared to the transient and sustained firing types (Pambo-Pambo et al., 2009; Leroy et al., 2014; Durand et al., 2015). Sustained (or immediate) firing motoneurons discharge regularly throughout the entire current pulse and represent the predominant group after P9 (Durand et al., 2015). The present work aimed to determine whether sustained or delayed-onset firing subgroups of SOD1 motoneurons are preferentially affected during this early period (Durand et al., 2015). For comparison with previous studies on SOD1 ${ }^{\mathrm{G} 85 \mathrm{R}}$ mice (Amendola et al., 2007; Bories et al., 2007; Filipchuk and Durand, 2012; Durand et al., 2015), we targeted the same pools of lumbar SOD1 ${ }^{\text {G93A-low }}$ motoneurons that send their axons into the fifth ventral roots (see McHanwell and Biscoe, 1981). Finally, we focused on the electrical properties of lumbar motoneurons in the G93A high-expressor mutants, as no electrophysiological studies were yet performed in the entire brainstem-spinal cord preparation of the SOD1 ${ }^{\text {G93A-high }}$ strain. Thus, we could for the first time compare the electrical properties of the lumbar motoneurons in the low- and high-expressor lines at the same age and in the "en bloc" preparation.

\section{EXPERIMENTAL PROCEDURES}

All surgical and experimental procedures were in conformity with the European Communities Council directive $(86 / 609 / E E C)$ and the ethic committee of the Institut de Neurosciences de la Timone $\left(n^{\circ} 71\right)$.

\section{Animals}

The generation and genotyping of transgenic mice was described previously (Amendola et al., 2004, 2007; Bories et al., 2007; Pambo-Pambo et al., 2009; Durand et al., 2015). We used three models of transgenic ALS mice expressing mutant versions of the human SOD1 gene: the SOD1 ${ }^{\text {G85R }}$ mice, line 148 (Bruijn et al., 1997; Bories et al., 2007), the SOD1 ${ }^{\text {G93A }}$ low expressor line (SOD1 ${ }^{\text {G93A-low }) ~ m i c e ~(D a l ~ C a n t o ~ a n d ~ G u r n e y, ~ 1997 ; ~}$ Pambo-Pambo et al., 2009), and the SOD $1^{\mathrm{G} 93 \mathrm{~A}}$ high expressor line (strain 4435), purchased from Jackson Laboratories (Gurney et al., 1994). Gur1-SOD1 ${ }^{\text {G93A }}$ mice were backcrossed to $\mathrm{C} 57 \mathrm{BL} / 6 \mathrm{~J}$ for at least 10 generations to generate this congenic strain (4435). The initial transgenic low expressor mice (G93A and G85R) were kindly provided by U382 INSERM-Marseille, and bred in our laboratory. These mice exhibit a delayed-onset of the phenotype compared to the original high copy numbers C57BL/6J-congenic SOD $1^{\text {G93A }}$ transgenic mice.

SOD $1^{\mathrm{G} 85 \mathrm{R}}$ mice were bred as homozygous and had an average survival of 240 days. SOD $1^{\text {G93A-low }}$ mice were obtained by crossing with $\mathrm{C} 57 \mathrm{BL} / 6 \mathrm{~J}$ to provide mixed litters of hemizygous transgenic and nontransgenic wild-type littermates. SOD1 ${ }^{\text {G93A-low }}$ mice survived an average of 200 days and SOD $1^{\text {G93A-high }}$ an average of 160 days. The genotypes of SOD $1^{\text {G93A }}$ mice were determined by RT-PCR on tail tips to check whether they carry the GLY to ALA mutation at base pair 93 of the SOD1 gene. The C57BL/6J (WT) strain, provided by Charles River Laboratories, was used as a control together with non-mutant SOD1 ${ }^{\text {G93A-low }}$ littermates. Preliminary studies showed that C57BL/6J and non-transgenic WT littermates displayed identical properties and could be safely pooled as WT controls. WT (C57BL/6J), non-transgenic WT littermates and SOD1 mutant mice have the same gestation length. Postnatal day 0 (P0) was defined as the first 24 hours after birth. We housed the mice in a temperaturecontrolled animal care facility with a 12-hours light-dark cycle. We made every effort to minimize animal suffering and the number of animals used.

\section{Surgical procedures: spinal cord/brainstem dissection}

Pups were anaesthetized by hypothermia, decerebrated at the post-collicular level, eviscerated and pinned to a Sylgard-coated Petri dish. Dorsal craniotomy and laminectomy were performed as described previously to allow the extraction of the spinal cord and brainstem (Bories et al., 2007; Amendola and Durand, 2008; 
Filipchuk and Durand, 2012), placed in a recording chamber, and superfused $(10 \mathrm{ml} / \mathrm{min})$ with an artificial cerebrospinal (ACSF) fluid containing (in $\mathrm{mM}$ ): $\mathrm{NaCl}, 130$; $\mathrm{KCl}, 4 ; \mathrm{MgCl}_{2}, 1.2 ; \mathrm{CaCl}_{2}, 2 ; \mathrm{NaH}_{2} \mathrm{PO}_{4}, 1 ; \mathrm{NaHCO}_{3}, 25$; glucose, 30; oxygenated with a $95 \% \mathrm{O}_{2} / 5 \% \mathrm{CO}_{2}$ mixture and adjusted to $\mathrm{pH} 7.4$. The bath temperature was maintained at $24^{\circ} \mathrm{C}$ by a servo-controlled Peltier device (Harvard TC-202A). The preparation was allowed to equilibrate for at least 1 hour before starting the recordings. Monopolar stainless-steel electrodes were placed in contact with the cut fifth lumbar (L5) ventral and dorsal roots and insulated with petroleum jelly for recordings and stimulations.

\section{Intracellular recordings and staining in the whole brainstem-spinal cord preparation}

Intracellular recordings were made in bridge mode using an Axoclamp 2B amplifier (Axon Instruments) with an output bandwidth of $3.0 \mathrm{kHz}$. Electrode resistance and capacitance were compensated before all the intracellular recordings. Signals were digitized at $10 \mathrm{kHz}$ by an $A / D$ converter (Digidata 1322 Axon Instruments) and recorded on a computer using Clampex 9.2 (Axon Instruments). The electrical properties were studied between P6 and P10 to allow the comparison with other studies (Bories et al., 2007; Elbasiouny et al., 2010; Quinlan et al., 2011; Leroy et al., 2014).

\section{Data analysis}

Data analysis was performed offline using Clampfit 9.2 (Axon Instruments). Input resistance (Rin) was measured as the slope of the linear portion of the current-voltage (I-V) relationship derived from series of hyperpolarizing and depolarizing $350-400 \mathrm{~ms}$ constant current pulses from $-0.4 \mathrm{nA}$ to $+0.4 \mathrm{nA}$ with $0.05 \mathrm{nA}$ steps. Measurements were taken from the averaged voltage over $10 \mathrm{~ms}$ from the steady-state membrane potential before and at the end of the pulses. Retained values were the averages of three sets of measurements.

The rheobase current was determined as the minimal current intensity required to evoke an action potential (AP) during the intracellular injection of the pulses. The voltage threshold of the AP was measured when the motoneuron fired its first AP. The AP amplitude and duration were measured on both the antidromic AP and the AP evoked by a direct intracellular current injection. Only motoneurons with stable membrane potential, an overshooting AP and amplitude greater than $50 \mathrm{mV}$ were kept for analysis. The primary time constant (Tau) was determined by fitting a double-exponential function to the first $20 \mathrm{~ms}$ of the membrane response to the break of a $0.5-\mathrm{ms}, 1 \mathrm{nA}$ hyperpolarizing current pulse. Retained values were the average of 15 measurements.

Firing behaviour was studied as described previously (Bories et al., 2007). Briefly, we used an intracellular injection of a series of depolarizing constant current pulses of increasing amplitude, with a duration of $800 \mathrm{~ms}$ to $1 \mathrm{~s}$. The frequency/current relationship was determined as the slope of the regression line fitted to the F-I curve in the steady-state (last $500 \mathrm{~ms}$ ). The $\mathrm{F}$-I relationship was linear along with the explored ranges of injected current in the steady-state. In the last set of electrophysiological experiments in SOD1 ${ }^{\text {G93A-high }}$ mice (Fig. 6), we also measured the slope of the F-I curve from the first interspike interval.

Non-transgenic WT littermates and SOD1 ${ }^{\mathrm{G} 93 \mathrm{~A}}$ mice aged between P8 and P9 were chosen because dendritic overbranching was observed precisely at this age in SOD1 ${ }^{\text {G85R }}$ mice (Amendola and Durand 2008) but not in P3-P4 mice (Filipchuk and Durand 2012). To allow microelectrode penetration, the pia was carefully removed medially to the L5 ventral root entry using very fine forceps under binocular control. Sharp micropipettes for intracellular recordings were made from $1.5 \mathrm{~mm}$ filament glass (Clark Instruments) using a pipette puller (model P-97; Sutter Instruments) and filled with $2 \mathrm{M}$ potassium acetate. Their resistances ranged between 60 and $100 \mathrm{M} \Omega$. The microelectrode was positioned to penetrate the L5 spinal segment with an angle of $30-45^{\circ}$ and advanced into the tissue using a Narishige threedimensional hydraulic microdrive. Motoneurons were impaled at a depth of $150-450 \mu \mathrm{m}$ from the spinal cord surface corresponding to the caudal part of the fifth lumbar segment. Motoneurons were intracellularly recorded following their identification using antidromic stimulation of the cut ventral root L5 or intracellular stimulation and orthodromic responses recorded from the cut ventral root (Bories et al., 2007). All motoneurons were located in the caudal part of the fifth lumbar segment and ventrolateral part of the spinal cord (McHanwell and Biscoe, 1981). A number of motoneurons were stained through sharp micropipettes containing $2 \%$ Neurobiotin in potassium acetate $2 \mathrm{M}$ (Vector, Burlingame, CA). The motoneurons were stained using positive current pulses (duration $150 \mathrm{~ms}$, current intensity $1-4 \mathrm{nA}$, frequency $3.3 \mathrm{~Hz}$ ) applied for 10-12 $\mathrm{min}$.

\section{Histological procedure and cell reconstructions}

One to two hours after labelling the motoneuron, the spinal cord was immersed in a fixative $(4 \%$ paraformaldehyde) overnight at $4{ }^{\circ} \mathrm{C}$, cut in blocks then rinsed with PBS ( $\mathrm{pH} 7.4)$. Each block was placed on a sliding microtome (Microm HM $650 \mathrm{~V}$ ) and cut in the transverse plane at $75 \mu \mathrm{m}$ thickness. The sections were mounted on slides and air-dried overnight. The neurobiotin was visualized using a standard avidin-HRP. diaminobenzidine staining procedure (Amendola and Durand, 2008).

The labelled motoneurons were reconstructed from serial sections ( $75 \mu \mathrm{m}$ thick) first on a Zeiss microscope equipped with a Camera Lucida attachment, then on a Nikon microscope equipped with a computer interfaced motorized stage and z-axis optical encoder using Neurolucida software. The Nikon microscope was equipped with an $\times 20$ dry objective and an $\times 3$ numerical zoom (final magnification $\times 60$ ). Shrinkage in section thickness was estimated by measuring the distance between the dendritic tips observed at the top and bottom of the histological section containing the cell body and the two adjacent sections. This value was divided by the original thickness of the section, giving 
the shrinkage factor. In most cases, we observed a 0.3 factor (range 0.25-0.39), and corrected the z-axis applied for each motoneuron based on its factor. No correction was applied in the $x-y$ axis which was measured in the live slices for comparison purposes. A single motoneuron was described by $6000-18,000$ data points stored in a database with fiducial marks (boundaries of transverse spinal cord sections and central canal) in ASC-format files. We added the motoneurons analyzed here to our database of digitized neurons fully reconstructed following Neurobiotin intracellular staining. Digital images were obtained with an Olympus confocal microscope (FV500) running Fluoview 5.0 software.

\section{Morphological measurements with Neurolucida ${ }^{\mathrm{TM}}$ software}

Following the $3 \mathrm{D}$ reconstruction with NeurolucidaT, $a$ number of morphological parameters were calculated for each motoneuron, such as the soma perimeter measured in the transverse plane $\left(P_{\text {trans }}\right)$, the area enclosed by the soma contour in the transverse plane $\left(A_{\text {trans }}\right)$, the estimated 3D soma surface area $\left(A_{\text {soma }}\right)$, the maximal centrifugal order - highest observed order (Order ${ }_{\text {max }}$, the most frequent centrifugal order (order attributed to the majority of dendritic segments) (Order $\left.{ }_{\text {mean }}\right)$, the mean topologic asymmetry index (Asymmetrytopol) which varies between zero for symmetric trees, to one for maximally asymmetric trees (van Pelt et al., 1997), the total dendritic path length $\left(\Sigma_{\mathrm{L}}\right.$ Total $)$, the total dendritic surface area $\left(\Sigma_{\text {Area }}\right)$, the total dendritic volume $\left(\Sigma_{\text {Volume }}\right)$, the average stem diameter $\left(\mathrm{d}_{\text {stem }}\right)$,

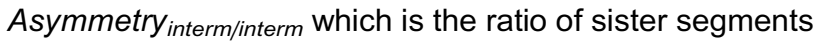
lengths over all pairs where both branches are intermediate (1 means symmetrical pair), averaged over each motoneuron, the ratio of sister segments lengths over all pairs where both branches are terminal (1 means symmetrical pair), averaged (Asymmetry term/term ), the percentage of terminal segments shorter than $35 \mu \mathrm{m}$ (Short terminals $(<35 \mu \mathrm{m})$ ), the volume (convex hull) encased by an elastic surface wrapped around the entire neuron, stretched between the most distal points of adjacent processes $\left(V_{\text {Convex hull }}\right)$, the area of convex hull surface $\left(A_{\text {con- }}\right.$ vex hull), the longest dendritic path from soma to ending $\left(P a h_{\max }\right)$, the longest Euclidian distance from soma to ending (radius of a sphere with a center in soma, containing the whole enclosing dendritic tree) (Radial max ), the dendritic path distance from soma to all terminations averaged over the whole arborization $\left(\right.$ Path $\left._{\text {mean }}\right)$, and the maximum of 3D Sholl's function (maximal number of intersections between dendrites and a concentric sphere)

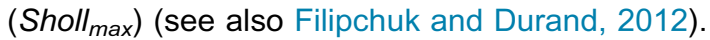

The topology-related parameters were the number of stem dendrites $\left(\mathrm{N}_{\text {stem }}\right)$ and the total number of branching points ( $\mathrm{N}$ nodes). To estimate general sizerelated characteristics of a neuron, we used a set of the following parameters: total dendritic length, total dendritic surface area, mean dendritic diameter, mean stem diameter. Max of Sholl function is the maximal number of dendritic elements (e.g. nodes or endings) per unit spherical layer at a certain radial distance from
Table 1. Comparison between morphological parameters of WT $(n=11)$ and SOD1 G93A-low motoneurons $(n=4)$ intracellularly stained with neurobiotin (3D reconstruction using Neurolucida ${ }^{\mathrm{TM}}$ ). All $P$ values are calculated using non-parametric Mann-Whitney $U$ test

\begin{tabular}{|c|c|c|c|}
\hline $\begin{array}{l}\text { Morphological } \\
\text { parameters }\end{array}$ & $\mathrm{WT}(n=11)$ & $\begin{array}{l}\text { SOD1-G93A } \\
(n=4)\end{array}$ & $p$ \\
\hline$A_{\text {trans }}\left(\mu \mathrm{m}^{2}\right)$ & $754 \pm 137$ & $877 \pm 109$ & ns \\
\hline$A_{\text {soma }}\left(\mu \mathrm{m}^{2}\right)$ & $3100 \pm 800$ & $3189 \pm 400$ & ns \\
\hline $\mathrm{N}$ stem & $7.7 \pm 2$ & $10 \pm 2$ & ns \\
\hline $\mathrm{N}$ nodes & $73 \pm 22$ & $141 \pm 36$ & 0.0015 \\
\hline Order $_{\text {Max }}$ & $7.82 \pm 1.08$ & $9.00 \pm 1.41$ & ns \\
\hline Order $_{\text {Mean }}$ & $3.27 \pm 0.47$ & $4.25 \pm 0.5$ & 0.014 \\
\hline d stem $(\mu \mathrm{m})$ & $5.53 \pm 1.3$ & $5.16 \pm 0.7$ & ns \\
\hline$\sum_{\mathrm{L} \text { Total }}(\mu \mathrm{m})$ & $\begin{array}{l}17,460 \\
\pm 5199\end{array}$ & $29,822 \pm 2543$ & 0.0015 \\
\hline$\sum_{\text {Area }}\left(\mu \mathrm{m}^{2}\right)$ & $\begin{array}{l}40,577 \\
\pm 15,009\end{array}$ & $\begin{array}{l}78,998 \\
\pm 12,288\end{array}$ & 0.003 \\
\hline$\sum$ Volume $\left(\mu \mathrm{m}^{3}\right)$ & $\begin{array}{l}12,920 \\
\pm 6169\end{array}$ & $24,260 \pm 6174$ & 0.018 \\
\hline Asymmetryterm-term & $0.52 \pm 0.06$ & $0.45 \pm 0.03$ & 0.038 \\
\hline $\begin{array}{l}\text { Short term-s } \\
\qquad(<35 \mu \mathrm{m}), \%\end{array}$ & $16.8 \pm 8.2$ & $37.5 \pm 9.3$ & 0.0058 \\
\hline Path $_{\operatorname{Max}}(\mu \mathrm{m})$ & $724 \pm 154$ & $744 \pm 71$ & ns \\
\hline Path $_{\text {Mean }}(\mu \mathrm{m})$ & $408 \pm 55$ & $468 \pm 38$ & 0.041 \\
\hline Radial $_{\text {Max }}(\mu \mathrm{m})$ & $483 \pm 42$ & $540 \pm 39$ & 0.039 \\
\hline Sholl Max & $50 \pm 14$ & $77 \pm 14$ & 0.04 \\
\hline$V$ convex hull $\mathrm{mm}^{3}$ & $\begin{array}{l}0.084 \\
\pm 0.026\end{array}$ & $\begin{array}{l}0.1597 \\
\pm 0.014\end{array}$ & 0.0014 \\
\hline A convex hull $\mathrm{mm}^{2}$ & $1.08 \pm 0.21$ & $1.55 \pm 0.08$ & 0.003 \\
\hline
\end{tabular}

the cell body (see Table 1). The convex hull analysis measures the size of the dendritic field by interpreting a branched structure as a solid object controlling a given amount of physical space. For a 3D analysis, it can be represented as a plastic sheet wrapped around the entire neuron, with the plastic stretched between the most distal points of adjacent processes. The volume encased by this plastic sheet is the volume calculated by the 3D convex hull analysis.

\section{Immunohistochemistry}

After hypothermia anaesthesia, we dissected the lumbar segments and fixed the tissue in paraformaldehyde. The lumbar spinal cords segments L4-L5 were cut transversally into $30 \mu \mathrm{m}$ thick sections with a vibratome (Microm, HM 650 V). Sections from two transgenic SOD1 and WT mice at P3 and P8 were mounted on the same slide and all slides (12) were processed simultaneously. The experiment was performed twice. Sections were permeabilized with Triton- $\mathrm{X} 100(0.2 \%$ in phosphate saline buffer containing $3 \%$ bovine serum albumin) and pre-incubated with normal goat serum (1\% in PBS 3\% BSA). Then, they were incubated overnight with a rabbit polyclonal Glial Fibrillary Acidic Protein (GFAP) or a rabbit polyclonal human synaptophysin antibodies (1/400 and 1/200 dilution, respectively; Dako Cytomation). After washing the sections in PBS $(3 \times 5 \mathrm{~min})$, they were incubated with a goat anti-rabbit IgG conjugated to Alexa-546 secondary antibody (diluted 1/400; Molecular Probes). Normal rabbit immunoglobulin fraction was used instead of primary 
antibodies as a negative control (same concentration as the primary antibody) and resulted in an absence of labelling. Slides were mounted in a gelatinous aqueous medium. Sections were scanned using a laser-scanning confocal microscope (Olympus FV 500) at $20 \times$ magnification. The fluorescent signal was analyzed using the Fluoview software (Olympus). A region of interest was drawn within the ventral horn (ventral motoneuron pool or surrounding white matter) and the mean pixel intensities were measured in this delimited area. Mean fluorescence intensities were normalized to WT for each slide.

\section{Statistical analysis}

Statistical significance was assessed using the nonparametric Mann Whitney $U$ test for independent and paired samples (GraphPad Prism 6 and StatXact7 software, Cytel studio Inc., Cambridge, MA, USA). 2tailed tests were used throughout the manuscript. Two groups of data were considered statistically different when $p<0.05\left({ }^{*}\right)$, and highly significant when $p<0.01$ $\left({ }^{* *}\right)$ or $p<0.005{ }^{(* *)}$. Results are expressed as medians \pm quartile unless specified otherwise in text or legends. Graphical representations were obtained using Prism 6 (GraphPad Software, Inc.) and Corel Draw 12 (Vector Capital, San Francisco, CA, USA).

\section{RESULTS}

Intracellular recordings of 78 antidromically identified lumbar motoneurons were performed in in vitro brainstem-spinal cord preparations from SOD1 ${ }^{\text {G93A-low }}$ $(N=11)$ and SOD1 ${ }^{\text {G93A-high }}(N=10)$ mice and their respective non-transgenic littermates $(N=19$ and $N=8$ ), for a total of 45 WT and 33 SOD $1^{\mathrm{G} 93 A}$ motoneurons. Among them, intracellular staining and full 3D complete reconstructions were obtained for 15 motoneurons of 15 mice ( 11 WT and 4 SOD $1^{\text {G93A-low }}$ ). Immunohistochemistry were performed in $4 \mathrm{WT}$ and 4 SOD1 ${ }^{\mathrm{G} 85 \mathrm{R}}$ mice.

\section{Dendritic overbranching occurs in lumbar motoneurons from SOD1 ${ }^{\text {G93A-low }}$ mice}

As previously found in SOD1 ${ }^{\mathrm{G} 85 \mathrm{R}}$ motoneurons (Amendola and Durand, 2008; Filipchuk and Durand, 2012), SOD $1^{\text {G93A-low }}$ motoneurons also have significantly larger dendritic trees than WT on postnatal days P8-P9 (Table 1). Examples of 3D reconstructions and dendrograms with an image of the two motoneurons are shown in Fig. 1 ( $\mathrm{A}$ : WT section containing the soma and proximal dendrites and $B$ : SOD $1{ }^{\text {G93A-low }}$ motoneurons). Indeed, the size of the soma ( $A_{\text {trans }}$ and $\left.A_{\text {soma }}\right)$ and the mean diameter of the primary dendrites ( $d$ stem) were not significantly different between populations (Table 1). The number of branching points was doubled in the SOD1 ${ }^{\text {G93A-low }}$ motoneurons compared to WT (Table 1, Nnodes). The average number of nodes and endings was plotted as a function of the radial distance from the soma $(25 \mu \mathrm{m}$ radius) to compare their radial location between the WT and SOD1 $1^{\text {G93A-low }}$ populations. The histogram of the radial location (Sholl's function) of the nodes indicates that the "extra-nodes" are mainly located between $150 \mu \mathrm{m}$ and $400 \mu \mathrm{m}$ of radial distance from the soma (Fig. 1C). The histogram of radial location of the dendritic endings shows that the "extra-endings" are mainly located between 200 and $450 \mu \mathrm{m}$ (Fig. 1D). The total dendritic length per motoneuron ( $\sum$ Ltotal; see Table 1$)$ is much greater in mutants than in WT mice (SOD1: $29,82 \pm 2.5 \mathrm{~mm}, n=4$; WT 17,46 $\pm 5,2 \mathrm{~mm}, n=11$; $p=0.0015$, Mann-Whitney $U$ test). Dendritic surface area and volume were also greater in SOD1 ${ }^{\text {G93A-low }}$ motoneurons than in WT (see Table 1). Other significant differences between WT and SOD $1^{\text {G93A-low }}$ concern Sholl's function, where the diameter of the sphere containing all dendrites increased from 483 to $540 \mu \mathrm{m}$ in SOD1 (Radial max in Table 1). Analysis of the convex hull demonstrated that the SOD $1^{\text {G93A-low }}$ motoneurons occupy more space in the spinal cord than the WT on postnatal days P8-P9 (Table 1). These morphological changes in the dendritic structure could have functional consequences, particularly on the integration of the synaptic current.

\section{Comparative morphology analysis of SOD ${ }^{\mathrm{G} 85 \mathrm{R}}$ and SOD1 ${ }^{\text {G93A-low }}$ P8-P9 motoneurons}

A comparative morphological analysis of $\mathrm{SOD} 1^{\mathrm{G} 93 \mathrm{~A}}$ (present study, $n=4)$ and SOD1 ${ }^{\mathrm{G} 85 \mathrm{R}}(n=6)$ motoneurons (Filipchuk and Durand 2012) indicates that most morphological parameters were similar in the two transgenic strains. This was the case, for example, for the soma area $\left(A_{\text {soma }}\right)$ (mean $\pm S D: 3189 \pm 400 \mu \mathrm{m}^{2}$ in G93A and $3545 \pm 1297 \mu \mathrm{m}^{2}$ in G85R) and the soma trans $\left(A_{\text {trans }}\right)\left(877 \pm 109 \mu \mathrm{m}^{2}\right.$ in G93A and 815 $\pm 176 \mu \mathrm{m}^{2}$ in G85R). This was also the case for the number of nodes (141 \pm 36 in G93A and $142 \pm 29$ in G85R), the total dendritic length per motoneuron (29822 $\pm 2543 \mu \mathrm{m}$ in G93A and $27485 \pm 6575 \mu \mathrm{m}$ in G85R), the total surface area $\left(78998 \pm 12288 \mu \mathrm{m}^{2}\right.$ in G93A and $59528 \pm 15355 \mu \mathrm{m}^{2}$ in G85R), the total dendritic volume $\left(24260 \pm 6173 \mu \mathrm{m}^{3}\right.$ in G93A and $16310 \pm 6187 \mu \mathrm{m}^{3}$ in G85R), the mean diameter of stem dendrites (5.16 $\pm 0.70 \mu \mathrm{m}$ in G93A and $5.72 \pm 1.82 \mu \mathrm{m}$ in G85R), the path max, $(744 \pm 71 \mu \mathrm{m}$ in G93A and $738 \pm 146 \mu \mathrm{m})$, the radial max, $(540 \pm 46 \mu \mathrm{m}$ in G93A and 472 $\pm 52 \mu \mathrm{m}$ ), the maximal centrifugal order (Order max) (9 \pm 1 in G93A and $11 \pm 3$ in G85R), the asymmetry topol, $(0.43 \pm 0.04$ in $\mathrm{G} 93 \mathrm{~A}$ and $0.46 \pm 0.03$ in G85R), the Asymmetry term/term $(0.45 \pm 0.03$ in G93A and 0.45 \pm 0.04 in G85R), the Asymmetry term/interm $(0.38 \pm 0.02$ in G93A and $0.40 \pm 0.03$ in G85R), Asymmetry interm/interm $(0.45 \pm 0.05$ in $\mathrm{G} 93 \mathrm{~A}$ and $0.44 \pm 0.05$ in G85R), the average length of terminal segments for each motoneuron $L_{\text {term }}(108 \pm 27 \mu \mathrm{m}$ in G93A and $113 \pm 15 \mu \mathrm{m}$ in G85R), the tortuosity, $(1.36 \pm 0.04$ in G93A and $1.36 \pm 0.13$ in G85R), and the Sholl $\max (77 \pm 16$ in G93A and 77 \pm 17 in G85R) (see also Table 1 in Filipchuk and Durand 2012).

We found differences for some morphological parameters between the two SOD1 strains, such as the

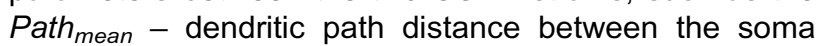
and all endings, averaged over the whole arborization 


\section{A}

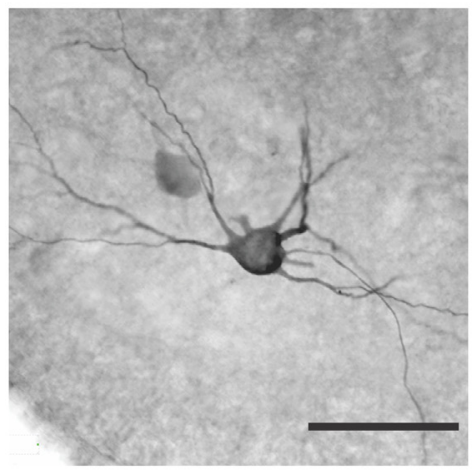

B

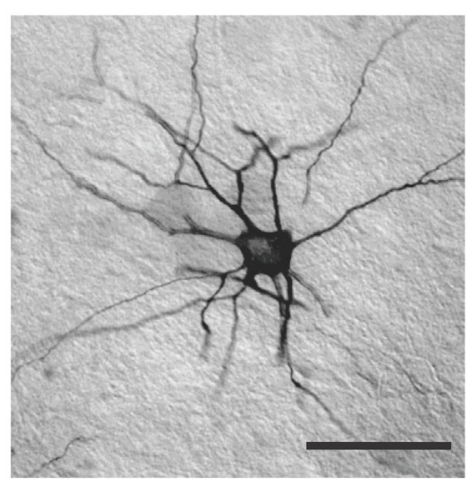

WT
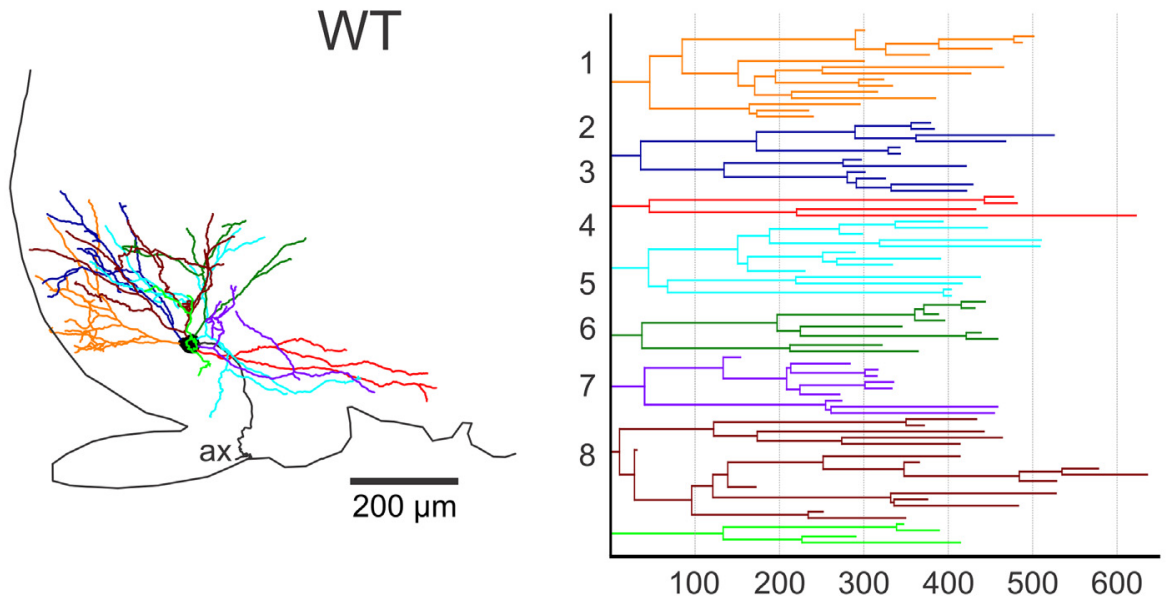

SOD $1^{\text {G93A-low }}$

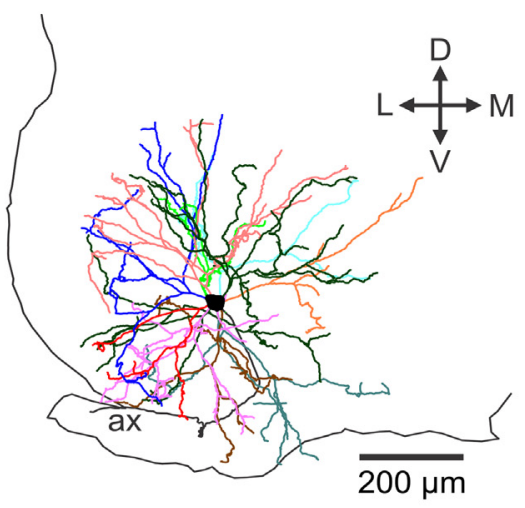

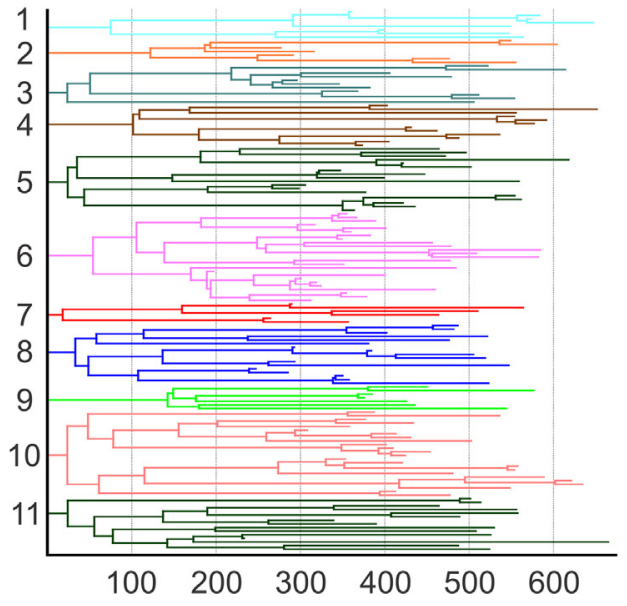

C

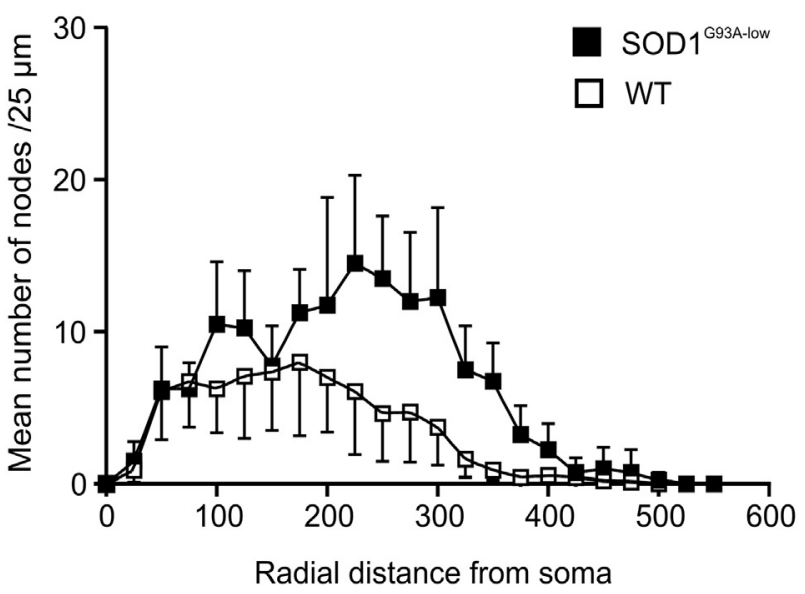

D

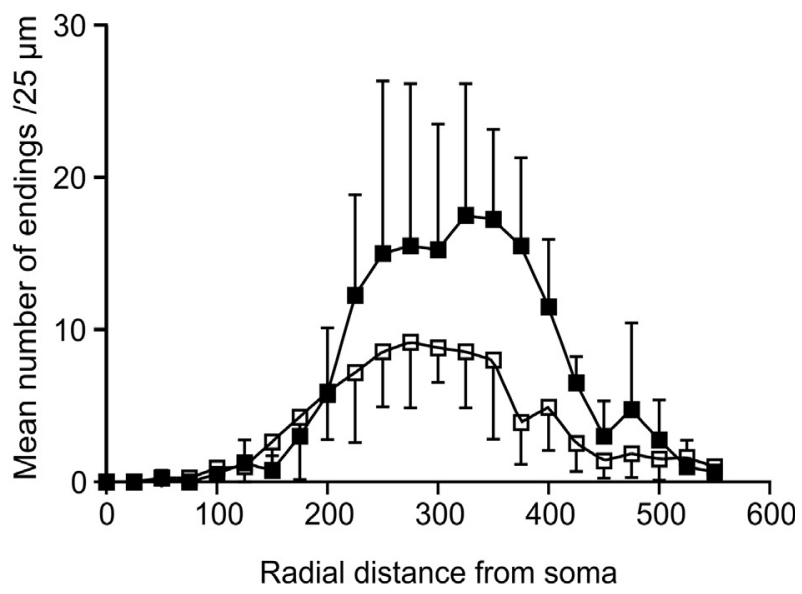

Fig. 1. Dendritic overbranching in lumbar motoneurons from SOD1 ${ }^{\text {G93A-low }}$ transgenic mice in the postnatal period P8-P9. Intracellularly stained WT (A) and SOD1 ${ }^{\text {G93A-low }}$ (B) motoneurons electrophysiologically identified following antidromic stimulation. Digital images show the section containing the cell body (left); digitized 3D reconstructions represent the full dendritic trees of motoneurons in a transverse view (middle); two-dimensional representations (dendrograms) obtained from the digitized reconstructions of the two motoneurons (right). Specific colours represent each dendrite. D, Dorsal, V, Ventral, L Lateral, and M, median. In C and D; Histograms of radial locations of nodes and endings for WT motoneurons $(n=11)$ and SOD $1^{\text {G93A-low }}$ motoneurons $(n=4)$. Sholl's function: plotting the location of elements of dendritic trees (e.g. nodes or endings) as a function of Euclidian distance from the neuron soma. Radial distance bin was $25 \mu \mathrm{m}$. The histograms reveal that "extra nodes" in the SOD1 motoneurons are located mainly between $150 \mu \mathrm{m}$ and $400 \mu \mathrm{m}$ of radial distance from the soma and extra-endings between $200 \mu \mathrm{m}$ and $450 \mu \mathrm{m}$ of radial distance from the soma. All results are mean $\pm \mathrm{SD}$. 
for each motoneuron (path mean was different: $469 \pm 38$ in G93A and $394 \pm 39$ in G85R $(p=0.02))$, the $V$ convex hull ( $V_{\text {Convex hull }}$ - the volume (convex hull) encased by an elastic surface wrapped around the entire neuron, stretched between the most distal points of adjacent processes. The $\mathrm{A}_{\text {Convex/hull }}$ (area of the convex hull surface) was also significantly different between both SOD1 strains (see Filipchuk and Durand 2012 for SOD $\left.1^{\mathrm{G} 85 \mathrm{R}}\right)$. These differences suggest that SOD $1^{\mathrm{G} 93 \mathrm{~A}}$ motoneurons occupy more space in the ventral horn of the spinal cord than the SOD $1^{\mathrm{G} 85 \mathrm{R}}$ but show a comparable dendritic overbranching. Thus, we considered the possibility to pool morphological data (A trans, A soma, number of nodes, dendritic length, dendritic surface area) from SOD $1^{\mathrm{G} 85 \mathrm{R}}$ and SOD $1^{\mathrm{G} 93 \mathrm{~A}-\mathrm{low}}$ motoneurons to compare the morphologies in the sustained and delayedonset firing motoneurons (see Table 2).

\section{Expression of synaptophysin and GFAP in the lumbar cord}

The dendritic overbranching could be due to a delay in the arrival of terminals in the lumbar cord as suggested by our previous electrophysiological studies (Amendola et al., 2004). A delay in the maturation of the descending pathways would lead to a decrease in the number of terminal boutons reaching the ventral horn during this period of development. To test this hypothesis, we compared the expression of synaptophysin in the lumbar cord of
SOD $1^{\text {G85R }}$ and WT mice at postnatal days P3 and P8, precisely when abnormal dendritic overbranching occurs in SOD1 ${ }^{\mathrm{G} 85 \mathrm{R}}$ motoneurons (Amendola and Durand, 2008; Filipchuk and Durand, 2012). We also used immunohistochemistry for GFAP (glial fibrillary acid protein) since astrogliosis has been described in this G85R model (Bruijn et al., 1997, 1998; Rossi et al., 2008).

Expression and location of synaptophysin and GFAP were analyzed by immunohistochemistry in restricted lumbar segments (L4-L5) of WT and SOD1 ${ }^{\mathrm{G} 85 \mathrm{R}}$ mice and compared between regions of the spinal cord (dorsal, ventral, white matter, upper and lower central canal). Fig. 2A, B illustrates the staining of synaptophysin and GFAP at P3 and P8 in the region of motoneuronal pools. The intensity of the synaptophysin staining was significantly weaker at $\mathrm{P} 3$ and $\mathrm{P} 8$ in SOD $1^{\text {G85R }}$ mice (Fig. 2A) and the intensity of the GFAP staining was lower in the SOD1 motoneuronal pool at P8 (Fig. 2B). In other areas of the spinal cord (dorsal and central canal regions), the synaptophysin staining was also less intense in SOD1 ${ }^{\mathrm{G} 85 \mathrm{R}}$, except in white matter at both ages (not shown). The amount of GFAP staining in SOD1 mice was lower at P3 but not at P8 in the white matter (not shown). These data suggest delay in the arrival of descending pathways at the lumbar level and corroborate the findings on the abnormal dendritic elongation of SOD1 ${ }^{\mathrm{G} 85 \mathrm{R}}$ motoneurons at P3-P4 (Filipchuk and Durand, 2012).

Table 2. Morphological parameters measured with Neurolucida ${ }^{\mathrm{TM}}$ from 20 full 3D reconstructed WT $(n=11)$ and SOD1 $(n=9)$ motoneurons of the sustained and delayed-onset firing pattern subgroups. No difference in the soma size was found between sustained and delayed-onset firing types in WT animals (A trans; A soma, same as in Table 1). No significant difference in the soma size was detected between WT and SOD1. For this analysis, we pooled SOD $1^{\mathrm{G} 85 \mathrm{R}}$ and SOD1 ${ }^{\mathrm{G} 93 \mathrm{~A}-\mathrm{low}}$ motoneurons in each subgroup, as dendritic overbranching was observed in both mutants at the same age (see Amendola and Durand, 2008, Filipchuk and Durand, 2012). A trans $\left(\mu \mathrm{m}^{2}\right)$ soma diameter; A soma $\left(\mu \mathrm{m}^{2}\right)$ soma surface area. Number of nodes, branching sites number; Dendritic length $(\mu \mathrm{m})$, total dendritic length per motoneuron; Dendritic surface area: total dendritic surface area per motoneuron $\left(\mu \mathrm{m}^{2}\right)$. Dendritic overbranching mainly occurs in the sustained firing motoneurons and is less pronounced in the delayed-onset firing motoneurons. It should be noted that the sustained and delayed-onset firing subgroups have comparable total dendritic lengths and dendritic surface area. Values are mean \pm SD. Statistical differences using the Mann-Whitney $U$ test are indicated in the last column (P1) for WT and SOD1 comparisons, and in rows below each parameter (P2) for sustained and delayed-onset firing patterns comparisons

\begin{tabular}{|c|c|c|c|c|}
\hline Morphological parameters from 3D reconstruction & Discharge firing pattern group & WT $(n=11)$ & $\operatorname{SOD} 1(n=9)$ & $\mathrm{P} 1$ \\
\hline \multirow[t]{2}{*}{ A trans $\left(\mu \mathrm{m}^{2}\right)$} & Sustained & $767 \pm 150(n=8)$ & $751 \pm 75(n=5)$ & ns \\
\hline & Delayed & $718 \pm 108(n=3)$ & $784 \pm 184(n=4)$ & ns \\
\hline P2 & & ns & ns & \\
\hline \multirow[t]{2}{*}{ A soma $\left(\mu \mathrm{m}^{2}\right)$} & Sustained & $3292 \pm 845$ & $3657 \pm 1065$ & ns \\
\hline & Delayed & $2588 \pm 406$ & $2791 \pm 699$ & ns \\
\hline $\mathrm{P} 2$ & & ns & ns & \\
\hline \multirow[t]{2}{*}{ Number of Nodes } & Sustained & $\begin{array}{l}68 \pm 23 \\
(34-101)\end{array}$ & $\begin{array}{l}153 \pm 30 \\
(120-178)\end{array}$ & 0.0015 \\
\hline & Delayed & $\begin{array}{l}85 \pm 13 \\
(74-100)\end{array}$ & $\begin{array}{l}124 \pm 28 \\
(93-157)\end{array}$ & ns \\
\hline P2 & & ns & ns & \\
\hline \multirow[t]{2}{*}{ Dendritic Length $(\mu \mathrm{m})$} & Sustained & $\begin{array}{l}17,115 \pm 6134 \\
(8730-26,245)\end{array}$ & $\begin{array}{l}29,772 \pm 3296 \\
(25,780-33,352)\end{array}$ & 0.0031 \\
\hline & Delayed & $\begin{array}{l}18,380 \pm 1321 \\
(17,211-19,813)\end{array}$ & $\begin{array}{l}24,611 \pm 4589 \\
(18,134-28,945)\end{array}$ & ns \\
\hline P2 & & ns & ns & \\
\hline \multirow[t]{2}{*}{ Dendritic Surface area $\left(\mu \mathrm{m}^{2}\right)$} & Sustained & $\begin{array}{l}39,743 \pm 16,553 \\
(19,833-68,307)\end{array}$ & $\begin{array}{l}75,682 \pm 14,296 \\
(58,488-95,279)\end{array}$ & 0.011 \\
\hline & Delayed & $\begin{array}{l}42,802 \pm 12,536 \\
(31,937-56,517)\end{array}$ & $\begin{array}{l}56,208 \pm 17,289 \\
(34,613-76,882)\end{array}$ & ns \\
\hline P2 & & ns & ns & \\
\hline
\end{tabular}



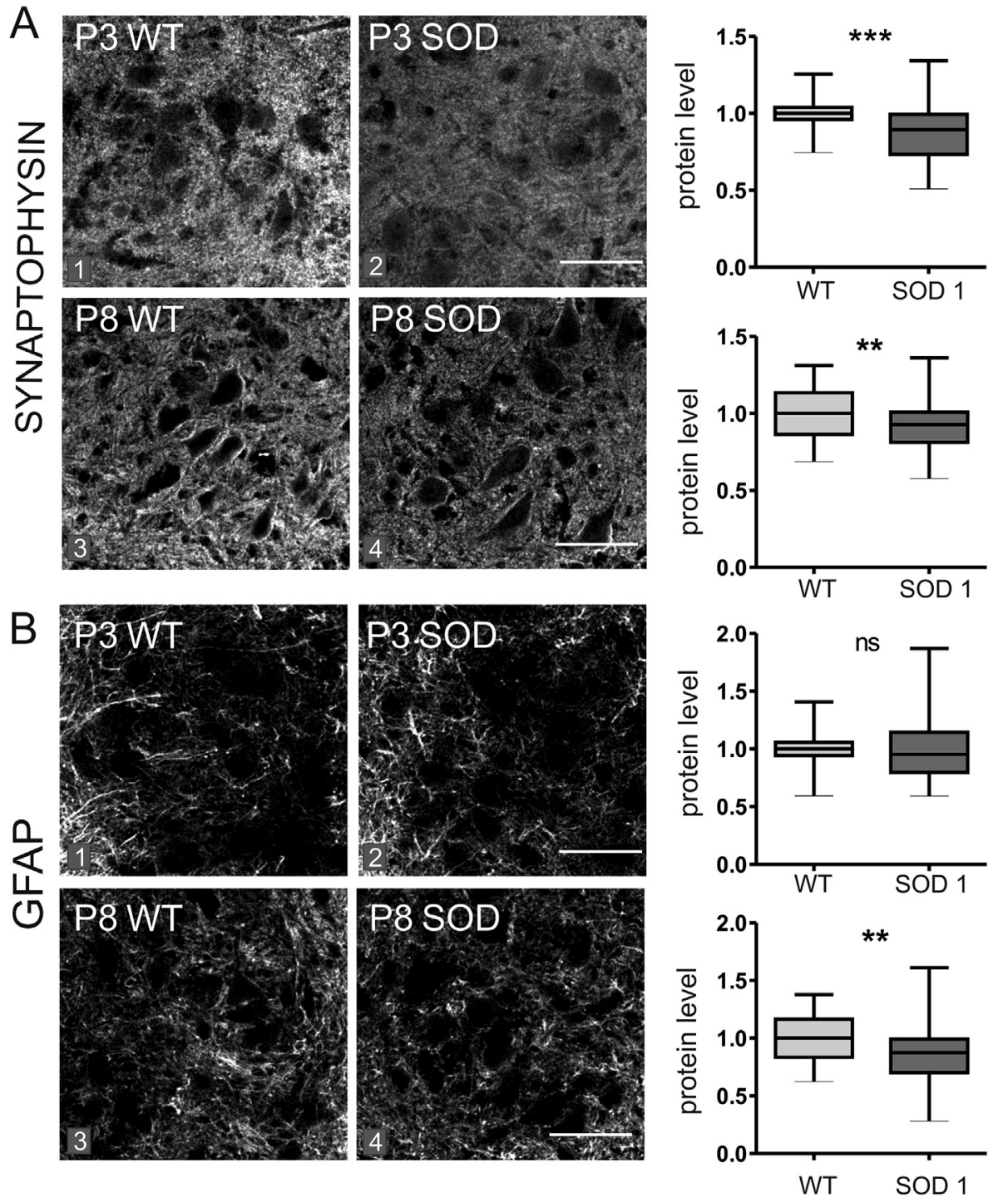

Fig. 2. Immunolocalization of Synaptophysin and GFAP proteins in the motoneuronal pools of the L4-L5 spinal cord segments of WT and SOD1 ${ }^{\mathrm{G} 85 R}$ mice. Confocal images showing (A) Synaptophysin immunostaining in the ventral part of a lumbar segment at P3 and P8 (A1, A3: WT mice; A2, A4: SOD1 mice) (B) GFAP immunostaining in the ventral part of a lumbar segment at P3 and P8 (B1, B3: WT mice; B2, B4: SOD1 mice). Sections of two SOD1 and two WT mice at P3 and P8 were mounted on the same slide and processed simultaneously. Whisker box show the protein level intensity for synaptophysin and GFAP at each age (same line, right). The labelling intensity was measured in a defined ROI. Mean fluorescence intensities were normalized to WT. The detected signal significantly decreased at P3 and P8 for synaptophysin, and P8 for GFAP (Mann-Whitney test; ns, non-significant difference; ${ }^{* *} p<0.01 ;{ }^{* * *} p<0.005 ; N=4$ animals and 40 to 52 histological sections analyzed in each group). Scale bars, $100 \mu \mathrm{m}$.

\section{Morphological quantification of dendrites in sustained and delayed-onset firing subgroups}

Furthermore, we observed dendritic overbranching in all three SOD1 subgroups (transient, sustained, delayedonset firing). The case of transient firing motoneurons will not be taken into account in this morphological study on P8-P9 motoneurons because they are predominant at P0-P3 and rare after P4 (Vinay et al., 2000; Durand et al., 2015). We only stained and fully reconstructed one transient firing SOD1 ${ }^{\text {G93A-low }}$ motoneuron that will not be considered in the present study although well overbranched (not shown). Fig. 3 (A, B) illustrates typical recordings of sustained and delayed-onset firing lumbar motoneurons (see also Pambo-Pambo et al., 2009; Durand et al., 2015) and 3D reconstructions of two SOD1 motoneurons (Fig. 3C, D). In the examples shown in Fig. 3, the dendritic arborization of the sustained firing SOD1 motoneuron is much larger than that of the delayed-onset firing one due to a greater number of branches instead of a greater dendritic extension in the ventrolateral horn. Notice both motoneurons have the same ventro-lateral location.

In eleven WT and nine SOD1 motoneurons, we identified sustained and delayed-onset firing pattern motoneurons all located in the same ventro-lateral region of the spinal cord (see also Amendola and Durand, 2008). We compared morphological parameters from the two subgroups of P8-P9 motoneurons, No significant difference was detected in soma size between WT and SOD1 (A trans; A soma, Table 2; see methods) or between subgroups in each strain. However, the number of nodes, the total dendritic length, and the total dendritic surface area were significantly higher in the sustained firing group of SOD1 motoneurons compared to their WT counterparts. Morphological changes are much greater in the sustained firing type of SOD1 motoneurons, as measured by the number of nodes, the total dendritic length, and the total dendritic surface area. In the delayed-onset firing group, the mean values of these parameters also increase in SOD1 although not significantly compared to the corresponding WT motoneurons. Notice the lack of differences between the soma sizes of the sustained and delayed-onset firing types in WT animals (Table 2). In our hands, the dendritic arborizations of the sustained firing WT motoneurons were no smaller in size than those of the delayed-onset firing motoneurons (Table 2), in contrast to the results obtained in the slice experiments (Leroy et al., 2014). In the latter study, the morphological values of dendrites measured in slices were much lower than those obtained following full $3 D$ reconstructions in the whole brainstem-spinal cord preparation (Table 2). 
A

Sustained
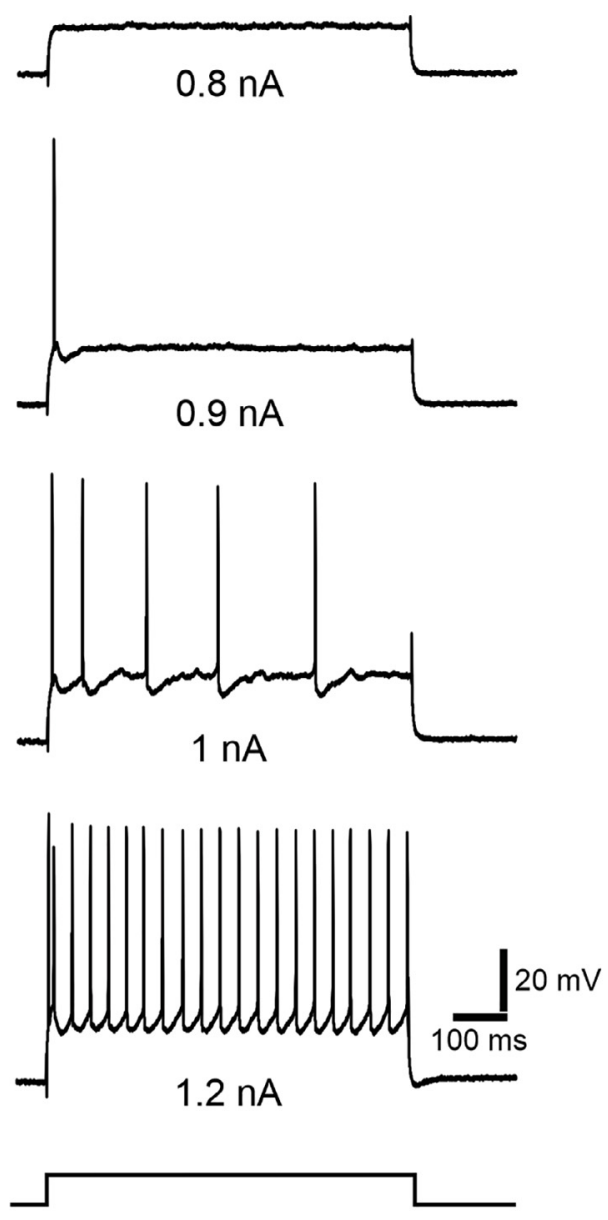

C

\section{Sustained}

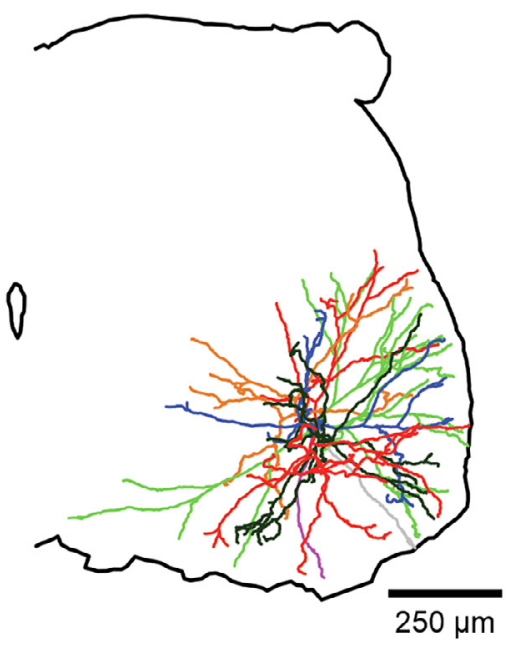

B Delayed
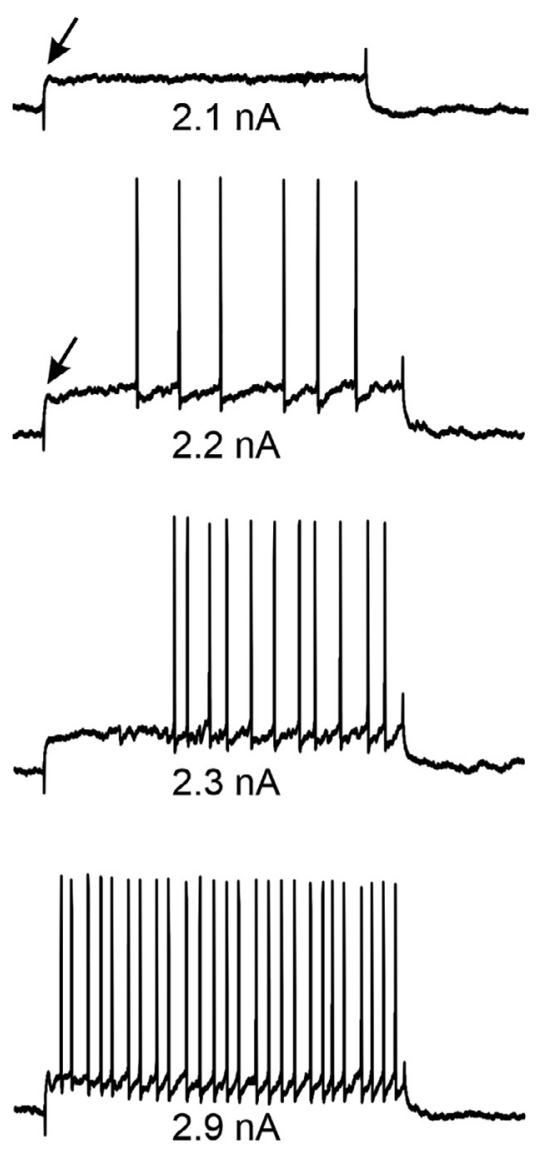

D Delayed

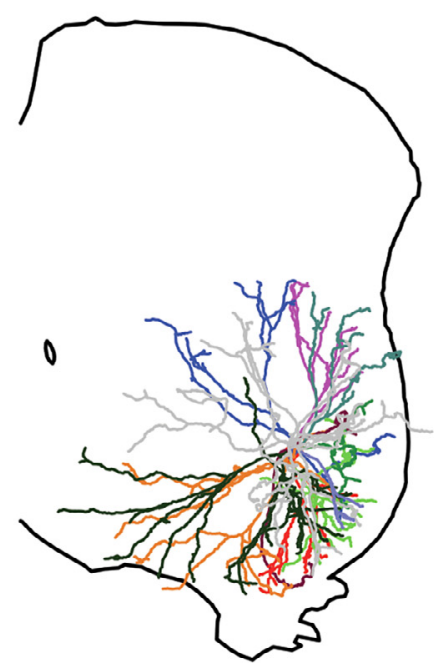

Hypoexcitability of SOD1 ${ }^{\text {G93A- }}$

low motoneurons in the delayedonset firing type

We then compared sixteen electrical properties recorded in lumbar motoneurons from SOD1 ${ }^{\text {G93A-low }}$ mice and their WT littermates between $\mathrm{P} 6$ and $\mathrm{P} 10$ (WT: $n=33$ cells, $N=18$ mice; SOD1 ${ }^{\text {G93A-low: }} \quad n=19$ cells, $N=12$ mice; first two columns of Table 3). Among them, only one parameter was found to be significantly different when analyzing the mean values of the whole populations, namely the amplitude of the action potential. A lower mean amplitude of the action potential was measured in SOD1 motoneurons ( $p=0.046$, Mann and Whitney $U$ test, 2tailed) (Table 3), as already described in slice recordings in the same strain (Pambo-Pambo et al., 2009). The action potential parameters were measured following antidromic stimulation (Fig. 4A1) or intracellular current injection (Fig. 4A3). The antidromic stimulation of the L5 ventral root sometimes evoked synaptic potentials giving rise to orthodromic action potentials (Fig. 4A2). Thus, a precise comparison of the spike shape parameters could be made between SOD1 ${ }^{\text {G93A-low }}$ motoneurons and their non-transgenic littermates (WT) motoneurons (Fig. 4B3 and Table 3). We found a lower gain in the SOD1 $1^{\text {G93A-low }}$ motoneurons $(24.4 \pm 3.0 \mathrm{~Hz} / \mathrm{nA})$ compared to WT $(30.5 \pm 1.8 \mathrm{~Hz})$ $n A$ ) (ns). The lowest gain was found in the population of delayed-onset firing motoneurons (WT: $37.24 \pm 3.35 \mathrm{~Hz} / \mathrm{nA}, n=9$; SOD1: $\quad 16.37 \pm 4.28 \mathrm{~Hz} / \mathrm{nA}$, $n=7 ; p=0.0052$; last columns of Table 3).

Fig. 4C illustrates the correlation between input resistance and age. Clear differences were seen between WT and SOD1 ${ }^{\text {G93A }}$ populations. Input resistance decreased steadily between P6 and P11 in WT motoneurons $(r=-0.45$, $p<0.005)$, but this highly significant negative correlation was not found for SOD1 ${ }^{\text {G93A-low }}$ motoneurons (Fig. 4C). There 
Table 3. Electrical properties of postnatal WT and SOD $1^{\text {G93A-low }}$ motoneurons. Sixteen electrical properties measured in WT $(n=33)$ and SOD $1^{\text {G93A }}$ low $(n=19)$ motoneurons (first two columns, all WT and all SOD1) recorded intracellularly in the entire brainstem-spinal cord preparation. In each subgroup defined by their firing pattern of discharge (transient, sustained or delayed-onset firing), comparisons between WT and SOD1 were made two by two in columns 3 and 4 (transient firing subgroup), columns 5 and 6 (sustained firing subgroup), and columns 7 and 8 (delayed-onset firing subgroup). See experimental procedures section for the details of electrical parameters. All values are mean \pm SEM. All $P$ values were calculated using the Mann-Whitney $U$ test and significant differences are indicated in bold. Non significant, ns

\begin{tabular}{|c|c|c|c|c|c|c|c|c|c|c|c|c|}
\hline & $\begin{array}{l}\text { All WT } \\
(n=33)\end{array}$ & $\begin{array}{l}\text { All } \\
\text { SOD1 } \\
(n=19)\end{array}$ & $P$ & $\begin{array}{l}\text { WT } \\
\text { Transient } \\
(n=9)\end{array}$ & $\begin{array}{l}\text { SOD1 } \\
\text { Transient } \\
(n=4)\end{array}$ & $P$ & $\begin{array}{l}\text { WT } \\
\text { Sustained } \\
(n=15)\end{array}$ & $\begin{array}{l}\text { SOD1 } \\
\text { Sustained } \\
(n=8)\end{array}$ & $P$ & $\begin{array}{l}\text { WT } \\
\text { Delayed } \\
(n=9)\end{array}$ & $\begin{array}{l}\text { SOD1 } \\
\text { Delayed } \\
(n=7)\end{array}$ & $P$ \\
\hline $\mathrm{Em}(\mathrm{mV})$ & $\begin{array}{l}-65,2 \\
\pm 1,1\end{array}$ & $\begin{array}{l}-64,4 \\
\pm 1,2\end{array}$ & $\mathrm{~ns}$ & $\begin{array}{l}-64,2 \\
\pm 1,6\end{array}$ & $\begin{array}{l}-67,7 \\
\pm 3,3\end{array}$ & ns & $\begin{array}{l}-63,2 \\
\pm 1,7\end{array}$ & $\begin{array}{l}-65,7 \\
\pm 1,4\end{array}$ & ns & $\begin{array}{l}-69,7 \\
\pm 2,2\end{array}$ & $\begin{array}{l}-61,1 \\
\pm 1,3\end{array}$ & 0,015 \\
\hline $\operatorname{Rin}(M \Omega)$ & $\begin{array}{l}17,1 \\
\pm 1,9\end{array}$ & $\begin{array}{l}18,4 \\
\pm 2,2\end{array}$ & ns & $\begin{array}{l}19,96 \\
\pm 4,71\end{array}$ & $\begin{array}{l}26,43 \\
\pm 3,68\end{array}$ & ns & $\begin{array}{l}18,12 \\
\pm 2,85\end{array}$ & $\begin{array}{l}15,45 \\
\pm 2,99\end{array}$ & ns & $\begin{array}{l}12,52 \\
\pm 1,55\end{array}$ & $\begin{array}{l}17,3 \\
\pm 4,13\end{array}$ & ns \\
\hline Gin $(n S)$ & $\begin{array}{l}74,4 \\
\pm 5,9\end{array}$ & $\begin{array}{l}71,1 \\
\pm 8,5\end{array}$ & ns & $\begin{array}{l}68,15 \\
\pm 13\end{array}$ & $\begin{array}{l}41,64 \\
\pm 5,56\end{array}$ & ns & $\begin{array}{l}67,43 \\
\pm 6,52\end{array}$ & $\begin{array}{l}82,08 \\
\pm 16,75\end{array}$ & ns & $\begin{array}{c}92,25 \\
\pm 13\end{array}$ & $\begin{array}{l}77,52 \\
\pm 12,86\end{array}$ & ns \\
\hline $\begin{array}{l}\text { First time } \\
\text { constant } \\
(20 \mathrm{~ms})\end{array}$ & $\begin{array}{l}3,2 \\
\pm 0,2\end{array}$ & $\begin{array}{l}3,1 \\
\pm 0,2\end{array}$ & ns & $\begin{array}{l}2,97 \\
\pm 0,38\end{array}$ & $\begin{array}{l}3,56 \\
\pm 0,57\end{array}$ & ns & $\begin{array}{l}2,98 \\
\pm 0,22\end{array}$ & $\begin{array}{l}2,83 \\
\pm 0,24\end{array}$ & ns & $\begin{array}{l}3,76 \\
\pm 0,34\end{array}$ & $\begin{array}{l}3,02 \\
\pm 0,29\end{array}$ & ns \\
\hline $\begin{array}{l}\text { Rheobase } \\
\text { (nA) }\end{array}$ & $\begin{array}{l}1,4 \\
\pm 0,2\end{array}$ & $\begin{array}{l}1,2 \\
\pm 0,1\end{array}$ & ns & $\begin{array}{l}0,85 \\
\pm 0,24\end{array}$ & $\begin{array}{l}1,00 \\
\pm 0,27\end{array}$ & ns & $\begin{array}{l}1,24 \\
\pm 0,21\end{array}$ & $\begin{array}{l}1,13 \\
\pm 0,22\end{array}$ & ns & $\begin{array}{l}2,25 \\
\pm 0,38\end{array}$ & $\begin{array}{l}1,29 \\
\pm 0,25\end{array}$ & ns \\
\hline $\begin{array}{l}\text { AP threshold } \\
(\mathrm{mV})\end{array}$ & $\begin{array}{l}-50,3 \\
\pm 1,8\end{array}$ & $\begin{array}{l}-49,2 \\
\pm 1,9\end{array}$ & ns & $\begin{array}{l}-51,36 \\
\pm 1,95\end{array}$ & $\begin{array}{l}-55,13 \\
\pm 2,5\end{array}$ & ns & $\begin{array}{l}-44,47 \\
\pm 2,46\end{array}$ & $\begin{array}{l}-49,28 \\
\pm 2,6\end{array}$ & ns & $\begin{array}{l}-59,04 \\
\pm 2,95\end{array}$ & $\begin{array}{l}-45,61 \\
\pm 3,78\end{array}$ & 0,033 \\
\hline $\begin{array}{l}\text { AP } \\
\text { amplitude } \\
(\mathrm{mV})\end{array}$ & $\begin{array}{l}59,4 \\
\pm 1,2\end{array}$ & $\begin{array}{l}55,9 \\
\pm 1,1\end{array}$ & 0,046 & $\begin{array}{l}55,17 \\
\pm 2,36\end{array}$ & $\begin{array}{l}55,43 \\
\pm 2,99\end{array}$ & ns & $\begin{array}{l}61,35 \\
\pm 1,41\end{array}$ & $\begin{array}{l}56,48 \\
\pm 1,59\end{array}$ & 0,022 & $\begin{array}{l}60,32 \\
\pm 2,61\end{array}$ & $\begin{array}{l}55,45 \\
\pm 1,99\end{array}$ & ns \\
\hline $\begin{array}{l}\text { Time to peak } \\
\text { (ms) }\end{array}$ & $\begin{array}{l}0,9 \\
\pm 0,08\end{array}$ & $\begin{array}{l}0,9 \\
\pm 0,07\end{array}$ & ns & $\begin{array}{l}1,09 \\
\pm 0,1\end{array}$ & $\begin{array}{l}1,1 \\
\pm 0,11\end{array}$ & ns & $\begin{array}{l}0,81 \\
\pm 0,04\end{array}$ & $\begin{array}{l}0,87 \\
\pm 0,05\end{array}$ & ns & $\begin{array}{l}0,75 \\
\pm 0,07\end{array}$ & $\begin{array}{l}0,86 \\
\pm 0,05\end{array}$ & ns \\
\hline $\begin{array}{l}\text { half width } \\
\text { (ms) }\end{array}$ & $\begin{array}{l}0,9 \\
\pm 0,09\end{array}$ & $\begin{array}{l}0,9 \\
\pm 0,1\end{array}$ & ns & $\begin{array}{l}1,05 \\
\pm 0,09\end{array}$ & $\begin{array}{l}1,33 \\
\pm 0,09\end{array}$ & ns & $\begin{array}{l}0,87 \\
\pm 0,05\end{array}$ & $\begin{array}{l}0,85 \\
\pm 0,02\end{array}$ & ns & $\begin{array}{l}0,74 \\
\pm 0,07\end{array}$ & $\begin{array}{l}0,84 \\
\pm 0,03\end{array}$ & ns \\
\hline $\begin{array}{l}\text { AP max } \\
\text { depol } \\
\text { slope } \\
(\mathrm{mV} / \mathrm{ms})\end{array}$ & $\begin{array}{l}149 \\
\pm 8,8\end{array}$ & $\begin{array}{l}124 \\
\pm 5,3\end{array}$ & ns & $113 \pm 14$ & $112 \pm 12$ & ns & $155 \pm 10$ & $126 \pm 6$ & ns & $\begin{array}{l}175 \\
\pm 19\end{array}$ & $128 \pm 11$ & ns \\
\hline $\begin{array}{l}\text { AP max } \\
\text { decay } \\
\text { slope } \\
(\mathrm{mV} / \mathrm{ms})\end{array}$ & $\begin{array}{l}-80 \\
\pm 4,6\end{array}$ & $\begin{array}{l}-68,4 \\
\pm 3,6\end{array}$ & $\mathrm{~ns}$ & $\begin{array}{l}-65,06 \\
\pm 6,99\end{array}$ & $\begin{array}{l}-48,67 \\
\pm 4,82\end{array}$ & ns & $\begin{array}{l}-78,03 \\
\pm 5,41\end{array}$ & $\begin{array}{l}67,1 \\
\pm 3,63\end{array}$ & ns & $\begin{array}{l}-98 \\
\pm 9,94\end{array}$ & $\begin{array}{l}-81,15 \\
\pm 4,59\end{array}$ & ns \\
\hline $\begin{array}{l}\text { Gain }(\mathrm{Hz} / \\
\quad \mathrm{nA}) \\
(n=24)\end{array}$ & $\begin{array}{l}30,5 \\
\pm 1,8\end{array}$ & $\begin{array}{l}24,4 \\
\pm 3,0\end{array}$ & ns & ND & ND & nd & $\begin{array}{l}27,71 \\
\pm 2,48\end{array}$ & $\begin{array}{l}31,39 \\
\pm 2,27\end{array}$ & ns & $\begin{array}{l}37,24 \\
\pm 3,35\end{array}$ & $\begin{array}{l}16,37 \\
\pm 4,28\end{array}$ & 0,005 \\
\hline $\begin{array}{l}\text { f-AHP } \\
\text { amplitude } \\
(\mathrm{mV})\end{array}$ & $\begin{array}{l}-6,3 \\
\pm 0,5\end{array}$ & $\begin{array}{l}-5,0 \\
\pm 0,6\end{array}$ & $\mathrm{~ns}$ & $\begin{array}{l}-4,60 \\
\pm 0,63\end{array}$ & $\begin{array}{l}-3,15 \\
\pm 1,40\end{array}$ & ns & $\begin{array}{l}-6,11 \\
\pm 0,87\end{array}$ & $\begin{array}{l}-4,51 \\
\pm 0,91\end{array}$ & ns & $\begin{array}{l}-8,16 \\
\pm 0,92\end{array}$ & $\begin{array}{l}-6,74 \\
\pm 0,63\end{array}$ & ns \\
\hline $\begin{array}{l}\text { S-AHP } \\
\text { amplitude } \\
\quad(\mathrm{mV})\end{array}$ & $\begin{array}{l}-6,1 \\
\pm 0,3\end{array}$ & $\begin{array}{l}-5,6 \\
\pm 0,5\end{array}$ & ns & $\begin{array}{l}4,93 \\
\pm 0,67\end{array}$ & $\begin{array}{l}-5,48 \\
\pm 1,71\end{array}$ & ns & $\begin{array}{l}-6,26 \\
\pm 0,5\end{array}$ & $\begin{array}{l}-5,36 \\
\pm 0,64\end{array}$ & ns & $\begin{array}{l}-6,88 \\
\pm 0,57\end{array}$ & $\begin{array}{l}-5,93 \\
\pm 0,86\end{array}$ & ns \\
\hline $\begin{array}{l}\text { AHP } 1 / 2 \\
\text { duration } \\
\quad(\mathrm{ms})\end{array}$ & $\begin{array}{l}32,3 \\
\pm 2,1\end{array}$ & $\begin{array}{l}38,6 \\
\pm 4,1\end{array}$ & ns & $\begin{array}{l}36,04 \\
\pm 4,88\end{array}$ & $\begin{array}{l}55,5 \\
\pm 15,95\end{array}$ & ns & $\begin{array}{l}29,79 \\
\pm 2,44\end{array}$ & $\begin{array}{l}35,15 \\
\pm 4,35\end{array}$ & ns & $\begin{array}{l}32,73 \\
\pm 4,63\end{array}$ & $\begin{array}{l}32,96 \\
\pm 3,39\end{array}$ & ns \\
\hline $\begin{array}{l}\text { AHP } \\
\text { duration } \\
\text { (ms) }\end{array}$ & $\begin{array}{l}64,7 \\
\pm 3,5\end{array}$ & $\begin{array}{l}76,3 \\
\pm 8,6\end{array}$ & ns & $\begin{array}{l}68,24 \\
\pm 6,52\end{array}$ & $121 \pm 33$ & ns & $\begin{array}{l}62,84 \\
\pm 4,56\end{array}$ & $\begin{array}{l}72,48 \\
\pm 5,17\end{array}$ & ns & $\begin{array}{l}64,43 \\
\pm 6,68\end{array}$ & $\begin{array}{l}55,10 \\
\pm 3,36\end{array}$ & ns \\
\hline
\end{tabular}

was a positive correlation between rheobase current and age $(r=0.36 . p<0.05)$, which increased with age in WT motoneurons (Fig. 4D). On the contrary, in SOD1 ${ }^{\text {G93A-low }}$ motoneurons, rheobase current tended to be negatively correlated to age $(r=-0.22$. ns) (Fig. 4D). The
SOD1 ${ }^{\text {G93A }}$ motoneuron shown in Fig. 3D had a high input resistance (39 $\mathrm{M} \Omega$ ) which is surprising given its developed dendritic arborization and large dendritic surface, that should have resulted in a low $R_{\text {in }}$. This example raised the question of whether the correlations

Fig. 3. (A, B) Examples of intracellular recordings of two SOD $1^{\text {G93A-low }}$ motoneurons with different firing patterns (sustained and delayed-onset). Membrane potential in $\mathbf{A},-70 \mathrm{mV}$ and in $\mathbf{B},-66 \mathrm{mV}$. (C, D): Full 3D reconstructions of two SOD $1^{\text {G93A- low }}$ motoneurons $\mathrm{n}^{\circ} 26$ (sustained) and $\mathrm{n}^{\circ} 25$ (delayed) both with supernumerary branches and sizes larger than that measured in WT motoneurons (see Table 2). Specific colours represent each dendrite. Motoneuron $\mathrm{n}^{\circ} 26$ : input resistance $39 \mathrm{M} \Omega$; nodes 191; length $33,352 \mu \mathrm{m}$; surface area $95,279 \mu \mathrm{m}^{2}$; Motoneuron $\mathrm{n}^{\circ} 25$ : input resistance $12.5 \mathrm{M} \Omega$; nodes 120 ; length $27,343 \mu \mathrm{m}$, surface area $65,469 \mu \mathrm{m}^{2}$. 


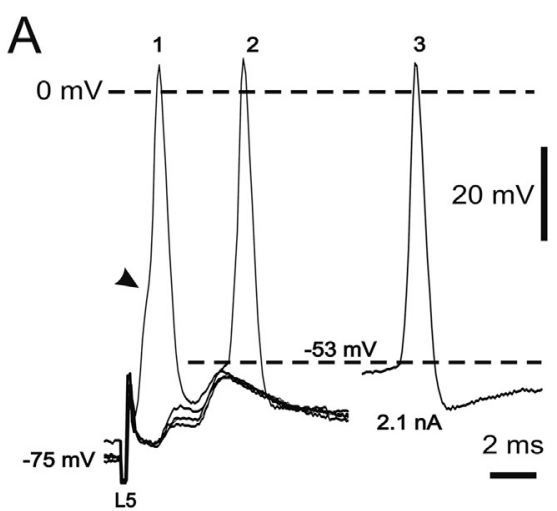

C

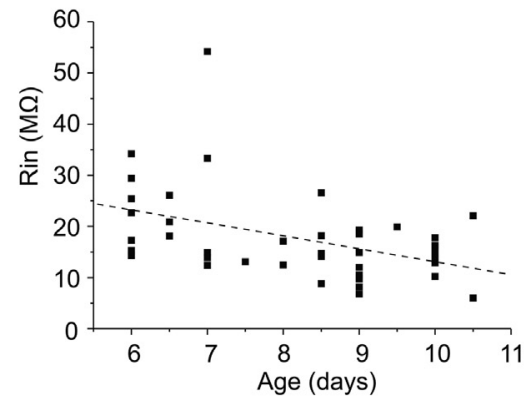

B

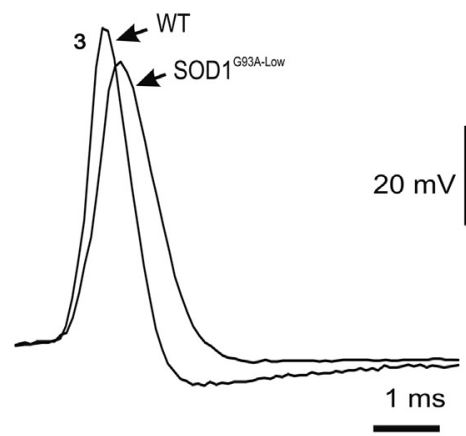

WT

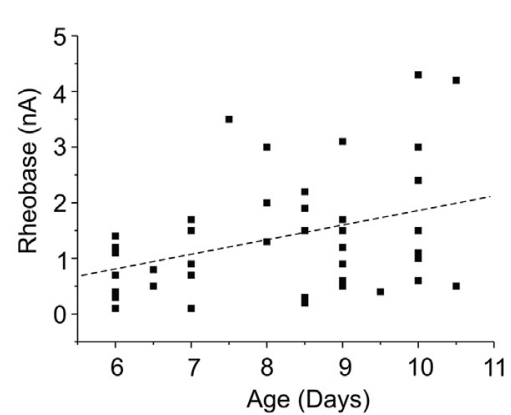

SOD $1^{\text {G93A-Low }}$
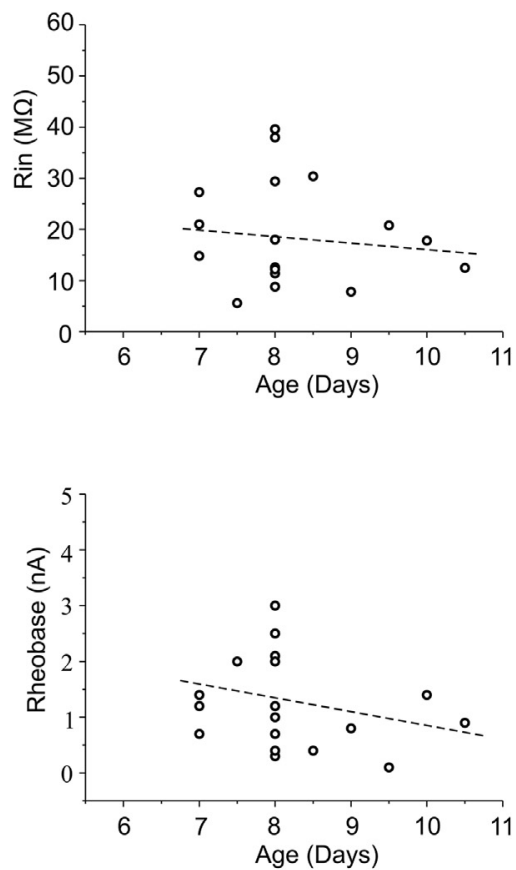

Fig. 4. Comparison between electrical properties of WT and SOD $1^{\text {G93A-low }}$ motoneurons populations. (A, B) Intracellular recording from identified lumbar motoneurons in the entire brainstem-spinal cord preparation showing an example of action potentials recorded from the same motoneuron following the antidromic electrical stimulation of the L5 ventral root for spikes 1 and 2 , and during an intracellular current pulse stimulation at the rheobase (spike 3). In B, two spikes obtained in WT and SOD1 ${ }^{\text {G93A-low }}$ are superimposed for comparison (see Table 3). (C, D), age evolution of

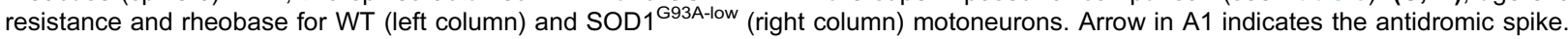

between electrical parameters, age and geometry were different between the WT and SOD1 motoneurons.

Comparison of the electrical properties between WT and SOD1 motoneurons reveals that the different subgroups of motoneurons were affected differently during their maturation (Table 3 , two columns for each subgroup).

In the delayed-onset firing population, the significant changes are the membrane potential, spike threshold and gain (Fig. $5 \mathrm{E}-\mathrm{H}$ ). The membrane potential was more depolarized in SOD1 motoneurons compared to WT ( $p=0.015$; Table 3 and Fig. $5 \mathrm{E})$ and the gain measured at the steady-state of the F-I curve much lower (Fig. $5 \mathrm{H})$. To a lesser extent, the spike threshold was higher in SOD1 (Fig. 5F). Thus, two electrical parameters have a tendency towards hypoexcitability (higher spike threshold and lower gain at the steadystate) and one towards hyperexcitability (membrane potential) in SOD1 ${ }^{\text {G93A-low }}$ motoneurons. No difference was found between WT and SOD1 sustained firing motoneurons for those electrical parameters (Fig. 5A-D). Only the spike amplitude (AP amplitude, Table 3) was significantly different between WT and SOD $1^{\text {G93A-low }}$ sustained firing motoneurons (WT: $61.35 \pm 1.41, n=15$; SOD1: $56 \pm 1.59, n=8, p=0.022$; Table 3).

\section{Hyperexcitability of SOD $1^{\text {G93A-high }}$ motoneurons in the sustained firing type}

This series of experiments was carried out to study, for the first time, the excitability of lumbar motoneurons in the entire brainstem/spinal cord preparation of the SOD1 ${ }^{\text {G93A-high }}$ mice during the postnatal period. In these experiments, intracellular recordings were performed in 44 lumbar motoneurons from SOD1 G93A-high mice $(N=9)$ and their non-transgenic WT littermates $(N=8)$. We found no differences in most electrical parameters between WT $(n=15)$ and SOD $1^{\text {G93A-high }}$ $(n=29)$ motoneurons between P6 and P10. All passive and active electrical membrane properties measured in our experiments were similar between SOD1 ${ }^{\text {G93A-high }}$ and their WT littermates. These electrical parameters include the membrane potential, input resistance, rheobase current, voltage threshold and spike amplitude (not shown). When comparing the whole populations of WT $(n=12)$ and SOD1 ${ }^{\text {G93A-high }}(n=14)$ motoneurons, no difference was observed in the $\mathrm{F}$-I slopes measured during the steady-state of the discharge (in the last $500 \mathrm{~ms}$ ), as done in previous studies (Bories et al., 2007; Durand et al., 2015). Most recorded motoneurons had a sustained firing pattern $(n=10$ WT and $n=10$ SOD1 ${ }^{\text {G93A-high }}$, Fig. 6D). Again, when the F-I slope was 

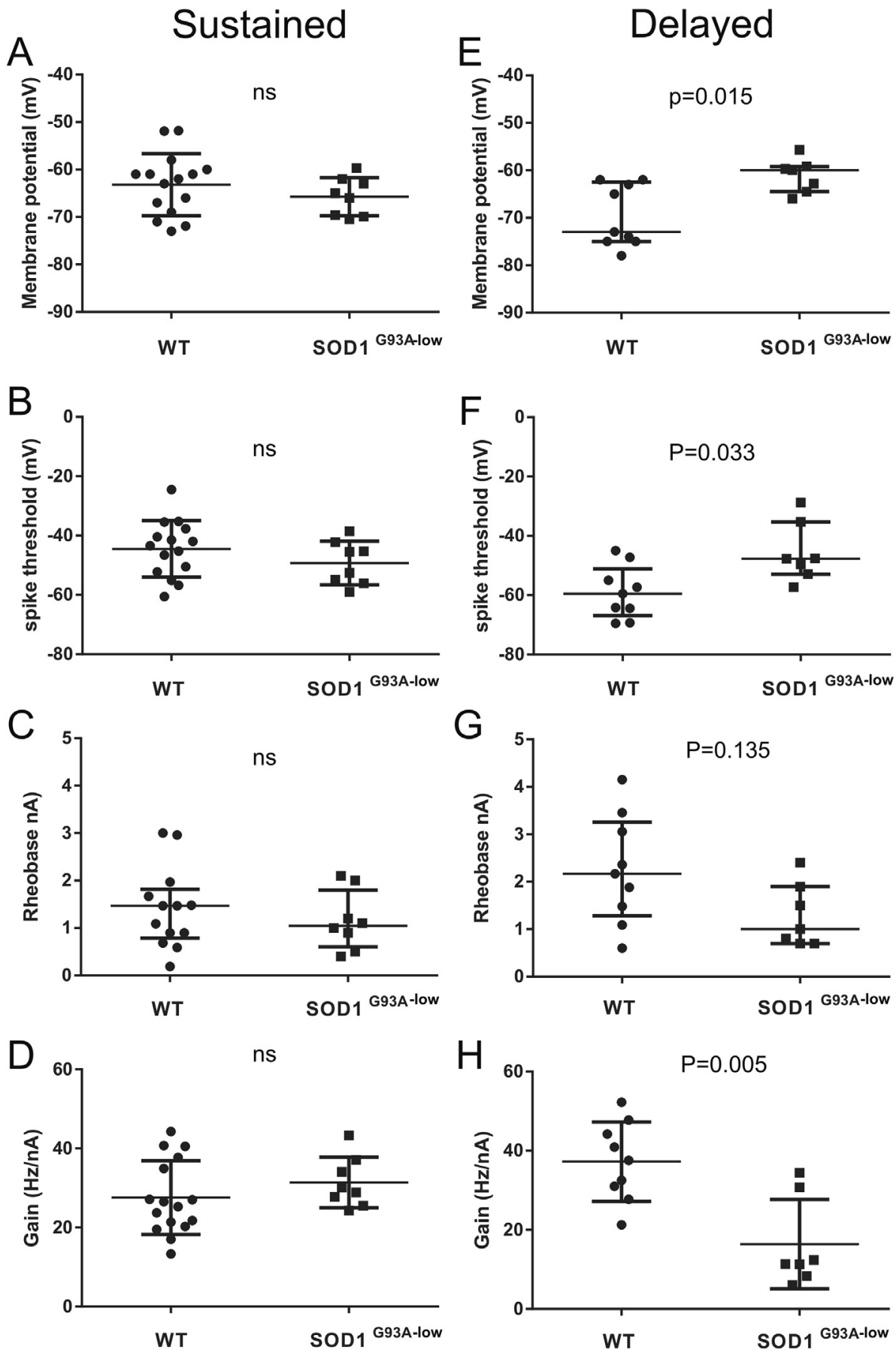

Fig. 5. Direct comparison between electrical properties of WT and SOD1 ${ }^{\text {G93A-low }}$ motoneurons subgroups according to their discharge firing pattern (sustained and delayed). Three electrical properties were significantly different between WT and SOD $1^{\text {G93A-low }}$ in the delayed-onset firing group $(\mathbf{E}-\mathbf{H})$ but not in the sustained (A-D). Notice the absence of motoneurons with high rheobase $(>3 n A)$ in the SOD1 delayed-onset subgroup (G). The mean membrane potential was significantly higher in SOD1 ${ }^{\text {G93A-low }}(E)$ as well as the spike threshold (F) giving the depolarization to threshold about equal. The gain was much lower in SOD1 $(\mathbf{H})$.

measured during the steady-state to analyze the gain of these sustained firing motoneurons, no difference was seen (Fig. 6D, upper graph). However, a significant difference was found between the two populations when the discharge frequency was measured within the first ISI ( $p=0.028$, Mann-Whitney test; Fig. 6D lower graph).
This result is in agreement with that obtained in the same strain by Leroy et al. (2014) using the same first ISI measurement.

\section{DISCUSSION}

In the present work, our results clearly demonstrate dendritic overbranching in SOD1G93A-low lumbar motoneurons compared to their non-transgenic WT littermates. Further we found an hypoexcitability in the delayedonset firing group of motoneurons in the SOD1 ${ }^{\text {G93A-low mice }}$ suggesting early precursor sign of the disease. Our quantitative analysis of their dendritic morphologies shows that overbranching is a common feature of both SOD1G93A-low motoneurons (this work) and lowexpressor SOD1 ${ }^{\mathrm{G} 85 \mathrm{R}}$ at the same age (P8-P9) (Amendola and Durand, 2008; Filipchuk and Durand, 2012). The dendritic overbranching analyzed from SOD $1^{\mathrm{G} 85 \mathrm{R}}$ and SOD1 ${ }^{\mathrm{G} 93 \mathrm{~A}}$ was more pronounced in sustained firing motoneurons although it was also present, but to a lesser extent, in delayed-onset firing motoneurons. The main differences in electrical properties were observed in the delayed-onset firing group of motoneurons in the SOD1 ${ }^{\text {G93A-low }}$ mice when compared to their WT littermates. Namely, early hypoexcitability (lower gain and higher voltage threshold) was confirmed in this subset of motoneurons. In the high-expressor strain, SOD1G93A-high, we found hyperexcitability of the sustained firing motoneurons at the same postnatal age suggesting that differences in electrical properties at a given time in the different strains (low versus high expressor lines) are due to different time courses of the disease.

\section{Dendritic overbranching occurs in SOD1 ${ }^{\text {G93A- low }}$ motoneurons}

The dendritic overbranching present in SOD1G93A-low mice lumbar motoneurons at postnatal age P8-P9 is comparable to that already described in the G85R strain (Amendola and Durand, 2008; Filipchuk and Durand, 2012). Indeed, the number of branches doubles in the SOD $1^{\text {G93A-low }}$ strain compared to WT (Table 1). The total 
A
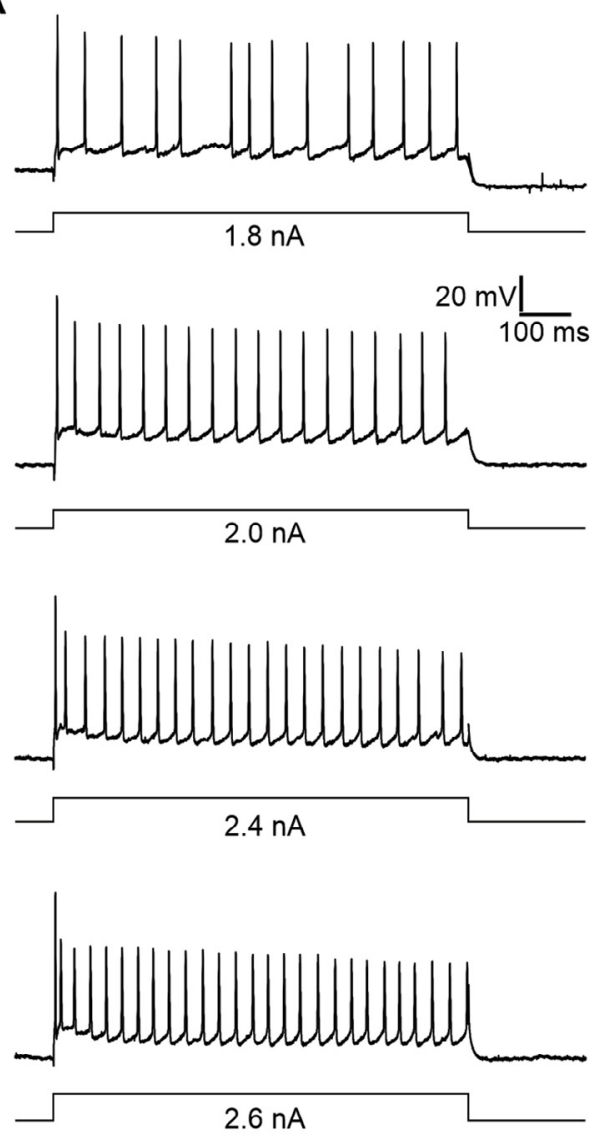

B
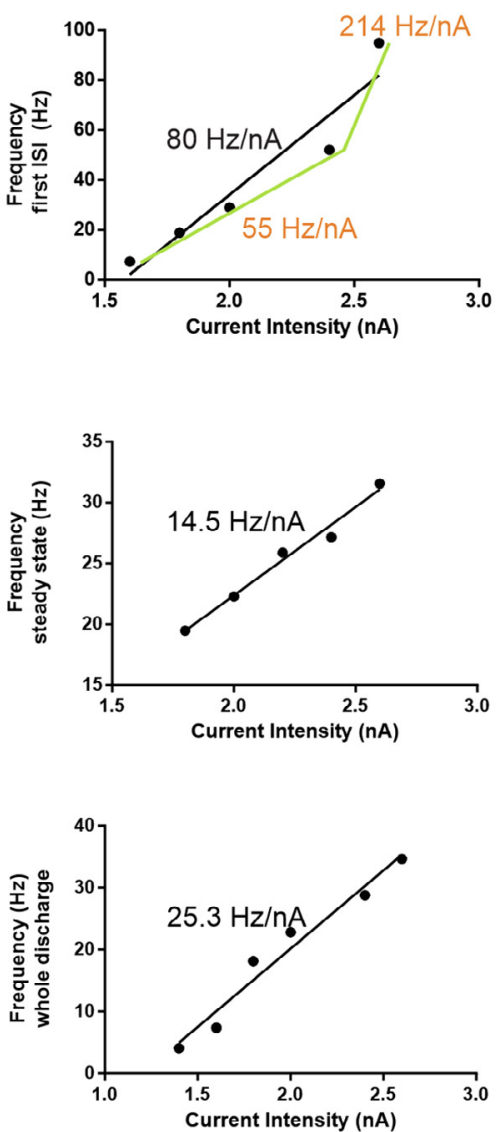

C

Whole population

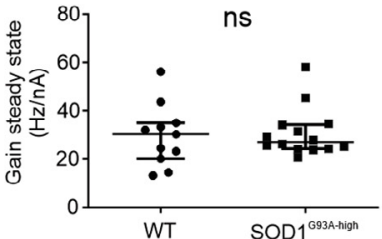

ns

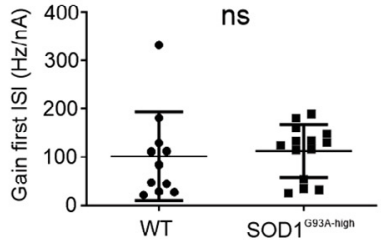

Sustained firing type
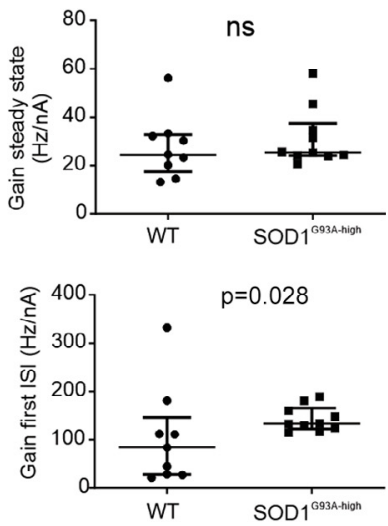

Fig. 6. Discharge pattern on constant current pulses stimulation in lumbar motoneurons from WT and SOD1 ${ }^{\text {G93A-high }}$ mice and hyperexcitability in the sustained firing group. (A) Four recordings of responses to the intracellular injection of constant current pulses of increasing intensity (upper to lower) in a WT motoneuron (Em $=-65 \mathrm{mV}$ ). The duration of each pulse is indicated by the black bar below each trace and the intensity of the injected current below each bar in nA. (B) Frequency/Intensity curves for the same motoneuron illustrated in A and measured at different times of the current pulse (firt ISI, at steady state or during the whole discharge). The frequency measured during the first ISI (first interval inter-spike (F-I in top trace in B) shows a primary range $(55 \mathrm{~Hz} / \mathrm{nA})$ followed by a secondary range $(214 \mathrm{~Hz} / \mathrm{nA})$ of discharge firing. The frequency values measured during the steady state of the discharge firing (B, F-I in middle trace) or during the whole discharge (B, F-I in bottom trace) are different for the same motoneuron $\left(14.5 \mathrm{~Hz} / \mathrm{nA}\right.$ and $25.3 \mathrm{~Hz} / \mathrm{nA}$, respectively). C. Both populations (WT and SOD1 ${ }^{\mathrm{G} 93 \mathrm{~A} \text {-high }}$ ) do not differ significantly for the gain with the different measurements when considering the whole populations of motoneurons at that postnatal ages (P6-P10). Medians with interquartile range are plotted in the graphs. D, In the sustained firing groups, F-I slopes measured during the first ISI (lower graph) show significant difference between WT and SOD1 populations ( $p=0.028$, Mann-Whitney test).

dendritic length and surface area measured for each motoneuron demonstrate an abnormal growth representing an $80 \%$ to $95 \%$ increase in this synapse-receiving structure. However, subtle morphological differences exist between the developing SOD $1^{\mathrm{G} 85 \mathrm{R}}$ and SOD $1^{\mathrm{G} 93 \mathrm{~A}-}$ low motoneurons, such as the greater convex hull volume in the G93A strain (Table 1, see methods) compared to the G85R. We previously discussed the cause of the dendritic overbranching (Durand et al., 2006; Amendola and Durand, 2008; Filipchuk and Durand, 2012). Here, we addressed whether the dendritic overbranching could be due to a lack of synaptic contacts during this maturation period and a delay in the arrival of some descending pathways, as previous studies suggested (Vinay et al., 2002; Amendola et al., 2004, 2007; Durand et al., 2006; Amendola and Durand, 2008).
A number of studies have shown a reduced staining of synaptophysin in adult presymptomatic SOD1 mice (Zang et al., 2005; Casas et al., 2013; Ohgomori et al., 2017) but no study has been done in postnatal mice. We found lower levels of synaptophysin at both P3 and P8 in all regions of lumbar cord (L4-L5) including motoneurons pools. Most motoneurons tend to overbranch at P8 and we showed supernumerary dendrites growing between P4 and P8 (Filipchuk and Durand, 2012). This supports the hypothesis of delayed maturation in SOD $1^{\mathrm{G} 85 \mathrm{R}}$ mice with a transient motor deficit only a week after birth (Amendola et al., 2004). We suggest the lack of synaptic boutons could trigger aberrant dendritic growth aimed at finding more synaptic connections to compensate for this deficit. Indeed, the link between reduced synaptophysin levels and dendritic overbranching of motoneurons is 
not yet established. The decrease level of GFAP immunostaining at P8 might be due to the death of astrocytes in the ventral horn of the lumbar region which may impact synaptic transmission to motoneurons (Carlsen and Perrier, 2014; Broadhead and Miles, 2020).

Dendritic overbranching was not observed in SOD $1^{\text {G93A-high }}$ at the same age but occurs probably later in this strain, as suggested in vivo (Delestree et al., 2014) and in vitro (Osking et al., 2019). In one study (Leroy et al., 2014), an overbranched motoneuron was found in SOD1 ${ }^{\text {G93-high }}$ mice between P6-P10 but excluded from the analysis. On the contrary, reduced dendritic trees in motoneurons were present in this strain at the embryonic stage (Martin et al., 2013), in the postnatal period (Leroy et al., 2014), and in adult SOD1 mice (Delestree et al., 2014).

\section{Alterations of excitability in the different subgroups of SOD1 motoneurons}

Our results clearly show an increase in the number of dendritic branches in most SOD1 motoneurons although less pronounced in the delayed-onset firing group. A reason why the latter developed fewer branches than the sustained firing motoneurons could be the greater accumulation of mutated proteins in hypoexcitable cells at this early age (Saxena et al., 2013). The overaccumulation of mutated proteins in hypoexcitable motoneurons would limit intracellular trafficking, precluding the dendritic ability to elongate in search of synaptic contacts. In fact, the lower gain of the delayed-onset firing motoneurons might be due to the accumulation of mutated SOD1 proteins in their cytoplasm and axon as shown to occur in the different strains (Saxena et al 2013).

The present work shows that a subset of SOD1 ${ }^{\text {G93A-low }}$ motoneurons (delayed-onset firing) exhibits early hypoexcitability, as measured by a lower gain in the F-I relationship and a higher voltage threshold (Fig. 5 and Table 3). In the SOD1 ${ }^{\text {G93A-high strain, we found }}$ hyperexcitability in another subset of motoneurons (sustained firing) (Fig. 6). This is in agreement with most studies showing an early hyperexcitability in motoneurons from the high expressor strain SOD1 G93A (Pieri et al., 2003; Quinlan et al., 2011; Leroy et al., 2014). In the high expressor G93A strain, an hypoexcitability of lumbar motoneurons was found in adult presymptomatic mice (Martínez-Silva et al., 2018).

iPSC derived from human patients with different ALScausing mutations displayed motoneuron hypoexcitability (Sareen et al., 2013; Renton et al., 2014; Devlin et al., 2015; Naujock et al., 2016; Sances et al., 2016). Direct lineage reprogramming also reveals hypo-activity of human ALS patients motor neurons (Liu et al., 2016). It is noteworthy that motoneurons recorded from ALS patients were hypoexcitable (Marchand-Pauvert et al., 2019). Hyperexcitability also develops in iPSC derived from ALS patients (Wainger et al., 2014) and was recorded in ALS patients (Vucic et al., 2014). Hyperexcitability may build throughout the course of the disease in resistant neurons, explaining why it is recordable from the remaining motor units in ALS patients.

\section{Overbranching, changes in voltage threshold and initial segment}

Our data show that the most branched part of the dendritic tree, which is supposed to receive the majority of synaptic contacts, was redistributed in the mutant motoneurons and moved away from the soma. This may be associated with modifications of afferent inputs with consequences on the axon initial segment. Ultrastructural alterations in the initial segment of motoneurons were described in SOD1 mice (Sasaki et al., 2005) and ALS patients (Sasaki and Iwata, 1996). A redistribution of initial segment voltage-gated $\mathrm{Na}^{+}$ channels and anchoring proteins was described following an afferent input modification in avian brainstem auditory neurons (Kuba et al., 2010). It has been shown that the orthodromic spike in the axon and the back-propagating spikes in the soma and dendrites depend on different types of sodium channels, differently distributed over the initial segment (Hu et al., 2009). Changes in voltage threshold can therefore be attributable to a pathological process and correspond to altered properties of the initial segment, including sodium channel types, density, and distribution, making the motoneuron more excitable.

\section{Firing patterns and maturation of motoneurons}

We previously showed that the different firing patterns reflect distinct maturation states, as revealed by action potential parameters (Durand et al., 2015). The transient firing pattern is the least mature, as also suggested by other studies (Vinay et al., 2000, 2002; Mentis et al., 2007). Indeed, we suggested that the delayed-onset firing group could correspond to the fast-fatigable motoneurons population in adult animals since the ratio of delayedonset firing motoneurons (25-30\%) in the entire brainstem-spinal cord preparation (Durand et al., 2015) would correspond to that of fast motoneurons expressing DIK1 (Muller et al., 2014). However, there is no direct demonstration that the delayed-onset firing motoneurons represent the fast motoneurons. It remains to be determined whether delayed-onset firing motoneurons express DIK1 (Muller et al., 2014). We did not observe the delayed-onset firing pattern after $P 9$ in the entire brainstem-spinal cord preparation although others reported a delayed-onset spike frequency acceleration in adult lumbar motoneurons of anaesthetized mice (Bos et al., 2018). This type of delayed-spike frequency acceleration appears to be uncommon in vivo as it has not been described in unanesthetized animals during the extensive pioneering work on the cat spinal cord.

In conclusion, this is the first time that electrical hypoexcitability is demonstrated in a subset of lumbar motoneurons during the postnatal period in SOD1 $1^{\text {G93A-low }}$ mice. Hypoexcitability has been proposed as a pathological mechanism in SOD1 mice (Saxena et al., 2013). These pathological signs start very early in motoneurons with accumulation of misfolded proteins detected in the fast-fatigable motoneurons population starting at P7 (Saxena et al., 2013). These FF motoneurons are the first to degenerate in most SOD1 strains (Hadzipasic et al., 2014). We suggest that functional 
hypoexcitability may lead to peripheral disconnection which start at different times in the high and low expressor lines explaining morphological and electrical changes at different times depending on the SOD1 strains of mice. Indeed, the reduced transmitter release at the fastfatigable neuromuscular junction observed in SOD1 ${ }^{\mathrm{G} 37 R}$ mice could be a consequence of motoneuronal hypoexcitability (Tremblay et al., 2017).

Pathological signs in SOD1 mice start very early in motoneurons (Saxena et al, 2013; Vinsant et al, 2013; Hadzipasic et al., 2014) indicating the urgency of early diagnosis and treatment of the disease, at least when the causal mutations are known.

\section{ACKNOWLEDGEMENTS}

This work was supported by CNRS, Aix Marseille Université, France, grant $n^{\circ} 11890$ from Association Française contre les Myopathies (AFM), Thierry Latran Foundation (OHEX Project) and Association pour la recherche sur la sclérose latérale amyotrophique et autres maladies du motoneurone (ARSLA), France. APP is a grant recipient from Government of Gabon. AF received a grant from the Ministère des Affaires Étrangères. The authors wish to thank Anne Duhoux for taking care of the animals.

\section{CONFLICT OF INTEREST STATEMENT}

The authors declare no conflict of interest.

\section{AUTHORS CONTRIBUTION}

AF and APP contributed equally to this work, collecting and analyzing the experimental data. AF, APP JPG and JD performed most of the electrophysiological data analysis, and AF performed all the morphological analysis including $3 \mathrm{D}$ reconstructions with Neurolucida. FG and JD performed the electrophysiological experiments on the high expressor line SOD1 ${ }^{\mathrm{G} 93 A}$. SL and $C B$ did immunohistochemistry. JD and JPG designed the research. All authors discussed the results and contributed to the manuscript.

\section{REFERENCES}

Amendola J, Durand J (2008) Morphological differences between wild-type and transgenic superoxide dismutase 1 lumbar motoneurons in postnatal mice. J Comp Neurol 511:329-341.

Amendola J, Gueritaud JP, D'Incamps BL, Bories C, Liabeuf S, Allene C, Pambo-Pambo A, Durand J (2007) Postnatal electrical and morphological abnormalities in lumbar motoneurons from transgenic mouse models of amyotrophic lateral sclerosis. Arch Ital Biol 145:311-323.

Amendola J, Verrier B, Roubertoux P, Durand J (2004) Altered sensorimotor development in a transgenic mouse model of amyotrophic lateral sclerosis. Eur J Neurosci 20:2822-2826.

Bories C, Amendola J, Lamotte d'Incamps B, Durand J (2007) Early electrophysiological abnormalities in lumbar motoneurons in a transgenic mouse model of amyotrophic lateral sclerosis. Eur $\mathrm{J}$ Neurosci 25:451-459.

Bos R, Harris-Warrick RM, Brocard C, Demianenko LE, Manuel M, Zytnicki D, Korogod SM, Brocard F (2018) Kv1.2 channels promote nonlinear spiking motoneurons for powering up locomotion. Cell Rep 22(12):3315-3327.
Bosco DA, Morfini G, Murat KN, Song Y, Gros-Louis F, Pasinelli P, Goolsby H, Fontaine BA, et al. (2010) Wild-type and mutant SOD1 share an aberrant conformation and a common pathogenic pathway in ALS. Nat Neurosci 13:1396-1403.

Broadhead MJ, Miles GB (2020) Bi-directional communication between neurons and astrocytes modulates spinal motor circuits. Front Cell Neurosci 14:30.

Bruijn LI, Becher MW, Lee MK, Anderson KL, Jenkins NA, Copeland NG, Sisodia SS, Rothstein JD, Borchelt DR, Price DL, Cleveland DW (1997) ALS-linked SOD1 mutant G85R mediates damage to astrocytes and promotes rapidly progressive disease with SOD1containing inclusions. Neuron 18:327-338.

Bruijn LI, Houseweart MK, Kato S, Anderson KL, Anderson SD, Ohama E, Reaume AG, Scott RW, Cleveland DW (1998) Aggregation and motor neuron toxicity of an ALS-linked SOD1 mutant independent from wild-type SOD1. Science 281:1851-1854.

Carlsen EM, Perrier J-F (2014) Purines released from astrocytes inhibit excitatory synaptic transmission in the ventral horn of the spinal cord. Front Neural Circuits 8.

Casas C, Herrando-Grabulosa M, Manzano R, Mancuso R, Osta R, Navarro X (2013) Early presymptomatic cholinergic dysfunction in a murine model of amyotrophic lateral sclerosis. Brain Behav 3:145-158. https://doi.org/10.1002/brb3.104. Published online 2013 Feb 17.

Dal Canto MC, Gurney ME (1997) A low expressor line of transgenic mice carrying a mutant human $\mathrm{Cu}, \mathrm{Zn}$ superoxide dismutase (SOD1) gene develops pathological changes that most closely resemble those in human amyotrophic lateral sclerosis. Acta Neuropathol 93:537-550.

Delestree N, Manuel M, Iglesias C, Elbasiouny SM, Heckman CJ, Zytnicki D (2014) Adult spinal motoneurones are not hyperexcitable in a mouse model of inherited amyotrophic lateral sclerosis. J Physiol 592:1687-1703.

Devlin A-C, Burr K, Borooah S, Foster JD, Cleary EM, Geti I, Vallier L, Shaw CE, Chandran S, Miles GB (2015) Human iPSC-derived motoneurons harbouring TARDBP or C9ORF72 ALS mutations are dysfunctional despite maintaining viability. Nat Commun 6:5999.

Durand J, Amendola J, Bories C, Lamotte d'Incamps B (2006) Early abnormalities in transgenic mouse models of amyotrophic lateral sclerosis. J Physiol, Paris 99:211-220.

Durand J, Filipchuk A, Pambo-Pambo A, Amendola J, Iryna Kulagina I, Gueritaud JP (2015) Developing electrical properties of postnatal mouse lumbar motoneurons. Front Cell Neurosci 9:349.

Elbasiouny SM, Amendola J, Durand J, Heckman CJ (2010) Evidence from computer simulations for alterations in the membrane biophysical properties and dendritic processing of synaptic inputs in mutant superoxide dismutase-1 motoneurons. J Neurosci 30:5544-5558.

Filipchuk AA, Durand J (2012) Postnatal dendritic development in lumbar motoneurons in mutant superoxide dismutase 1 mouse model of amyotrophic lateral sclerosis. Neuroscience 209:144-154.

Gurney ME, Pu H, Chiu AY, Dal Canto MC, Polchow CY, Alexander DD, Caliendo J, Hentati A, et al. (1994) Motor neuron degeneration in mice that express a human $\mathrm{Cu}, \mathrm{Zn}$ superoxide dismutase mutation. Science 264:1772-1775.

Hadzipasic M, Tahvildari B, Nagy M, Bianc M, Horwich AL, McCormick DA (2014) Selective degeneration of a physiological subtype of spinal motor neuron in mice with SOD1-linked ALS. PNAS 111:16883-16888.

Hegedus J, Putman CT, Gordon T (2007) Time course of preferential motor unit loss in the SOD1 G93A mouse model of amyotrophic lateral sclerosis. Neurobiol Dis 28(2):154-164.

Hegedus J, Putman CT, Tyreman N, Gordon T (2008) Preferential motor unit loss in the SOD1(G93A) transgenic mouse model of amyotrophic lateral sclerosis. J Physiol Lond 586:3337-3351.

Hu W, Tian C, Li T, Yang M, Hou H, Shu Y (2009) Distinct contributions of $\mathrm{Na}(\mathrm{v}) 1.6$ and $\mathrm{Na}(\mathrm{v}) 1.2$ in action potential initiation and backpropagation. Nat Neurosci 12:996-1002. 
Kanning KC, Kaplan A, Henderson CE (2010) Motor neuron diversity in development and disease. Ann Rev Neurosci 33:409-440.

Kuba H, Oichi Y, Ohmori H (2010) Presynaptic activity regulates $\mathrm{Na}$ $(+)$ channel distribution at the axon initial segment. Nature 465:1075-1078.

Kuo JJ, Siddique T, Fu R, Heckman CJ (2005) Increased persistent $\mathrm{Na}(+)$ current and its effect on excitability in motoneurones cultured from mutant SOD1 mice. J Physiol 563:843-854.

Leroy F, Lamotte d'Incamps B, Imhoff-Manuel RD, Zytnicki D (2014) Early intrinsic hyperexcitability does not contribute to motoneuron degeneration in amyotrophic lateral sclerosis. eLife 3:E04046.

Liu ML, Zang T, Zhang CL (2016) Direct lineage reprogramming reveals disease-specific phenotypes of motor neurons from human ALS patients. Cell Rep 14:115-128.

Marchand-Pauvert V, Peyre I, Lackmy-Vallee A, Querin G, Bede P, Lacomblez L, Debs R, Pradat PF (2019) Absence of hyperexcitability of spinal motoneurons in patients with amyotrophic lateral sclerosis. J Physiol 597:5445-5467.

Martin E, Cazenave W, Cattaert D, Branchereau P (2013) Embryonic alteration of motoneuronal morphology induces hyperexcitability in the mouse model of amyotrophic lateral sclerosis. Neurobiol Dis $54: 116-126$

Martínez-Silva ML, Imhoff-Manuel RD, Sharma A, Heckman CJ, Shneider NA, Roselli F, Zytnicki D, Manuel M (2018) Hypoexcitability precedes denervation in the large fastcontracting motor units in two unrelated mouse models of ALS. Elife 7.

McHanwell S, Biscoe TJ (1981) The localization of motoneurons supplyingthe hindlimbmuscles of the mouse. Philos Trans R Soc Lond B Biol Sci 293:477-508.

Mentis GZ, Diaz E, Moran LB, Navarrete R (2007) Early alterations in the electrophysiological properties of rat spinal motoneurones following neonatal axotomy. J Physiol Lond 582:1141-1161.

Muller D, Cherukuri P, Henningfeld K, Chor Hoon Poh L, Wittler GP, Schlüter O, Schmidt Jr Laborda J, Bauer SR, et al. (2014) Dlk1 promotes a fast motor neuron biophysical signature required for peak force execution. Science 343:1264-1266.

Naujock M, Stanslowsky N, Bufler S, Naumann M, Reinhardt P, Sterneckert J, Kefalakes E, Kassebaum C, et al. (2016) Aminopyridine induced activity rescues hypoexcitable motor neurons from amyotrophic lateral sclerosis patient-derived induced pluripotent stem cells: 4AP rescues ALS iPSC derived motor neurons. Stem Cells 34:1563-1575.

Ohgomori T, Yamasaki R, Takeuchi H, Kadomatsu K, Kira JI, Jinno S (2017) Differential involvement of vesicular and glial glutamate transporters around spinal alpha-motoneurons in the pathogenesis of SOD1(G93A) mouse model of amyotrophic lateral sclerosis. Neuroscience 356:114-124. https://doi.org/ 10.1016/i.neuroscience.2017.05.014. Epub 2017 May 17.

Osking Z, Ayers JI, Hildebrandt R, Skruber K, Brown H, Ryu D, Eukovich AR, Golde TE, et al. (2019) ALS-linked SOD1 mutants enhance neurite outgrowth and branching in adult motor neurons. iScience 19:448-449.

Pambo-Pambo A, Durand J, Gueritaud JP (2009) Early excitability changes in lumbar motoneurons of transgenic SOD1G85R and SOD1G(93A-Low) mice. J Neurophysiol 102:3627-3642.

Pieri M, Albo F, Gaetti C, Spalloni A, Bengtson CP, Longone P, Cavalcanti S, Zona C (2003) Altered excitability of motor neurons in a transgenic mouse model of familial amyotrophic lateral sclerosis. Neurosci Lett 351(3):153-156.

Pun S, Santos AF, Saxena S, Xu L, Caroni P (2006) Selective vulnerability and pruning of phasic motoneuron axons in motoneuron disease alleviated by CNTF. Nat Neurosci 9:408-419.

Quinlan KA, Schuster JE, Fu R, et al. (2011) Altered postnatal maturation of electrical properties in spinal motoneurons in a mouse model of amyotrophic lateral sclerosis. J Physiol Lond 589:2245-2260.
Renton AE, Chio A, Traynor BJ (2014) State of play in amyotrophic lateral sclerosis genetics. Nat Neurosci 17:17-23.

Robberecht W, Philips T (2013) The changing scene of amyotrophic lateral sclerosis. Nat Rev Neurosci 14:248-264.

Rosen DR, Siddique T, Patterson D, Figlewicz DA, Sapp P, Hentati A, Donaldson D, Goto J, et al. (1993) Mutations in Cu/Zn superoxide dismutase gene are associated with familial amyotrophic lateral sclerosis. Nature:36259-36262.

Rossi D, Brambilla L, Valori CF, Roncoroni C, Crugnola A, Yokota T, Bredesen DE, Volterra A (2008) Focal degeneration of astrocytes in amyotrophic lateral sclerosis. Cell Death Differ 15:1691-1700.

Sances S, Bruijn LI, Chandran S, et al. (2016) Modeling ALS with motor neurons derived from human induced pluripotent stem cells. Nature Neurosci 19:542-553.

Sareen D, O'Rourke JG, Meera P, Muhammad AKMG, Grant S, Simpkinson M, Bell S, Carmona S, et al. (2013) Targeting RNA foci in iPSC-derived motor neurons from ALS patients with a C9ORF72 repeat expansion. Sci Transl Med 5:149-208.

Sasaki S, Warita H, Abe K, Iwata M (2005) Impairment of axonal transport in the axon hillock and the initial segment of anterior horn neurons in transgenic mice with a G93A mutant SOD1 gene. Acta Neuropathol 110:48-56.

Sasaki S, Iwata M (1996) Impairment of fast axonal transport in the proximal axons of anterior horn neurons in amyotrophic lateral sclerosis. Neurology 47:535-540.

Saxena S, Cabuy E, Caroni P (2009) A role for motoneuron subtypeselective ER stress in disease manifestations of FALS mice. Nature Neurosci 12:627-636.

Saxena S, Roselli F, Singh K, Leptien K, Julien JP, Gros-Louis F, Caroni P (2013) Neuroprotection through excitability and mTOR required in ALS motoneurons to delay disease and extend survival. Neuron 80:80-96.

Taylor JP, Brown Jr RH, Cleveland DW (2016) Decoding ALS: from genes to mechanism. Nature 539:197-206.

Tremblay E, Martineau E, Robitaille R (2017) Opposite synaptic alterations at the neuromuscular junction in an ALS mouse model: when motor units matter. J Neurosci 37:8901-8918.

Van Zundert B, Peuscher MH, Hynynen M, Chen A, Neve RL, Brown Jr RH, Constantine-Paton M, Bellingham MC (2008) Neonatal neuronal circuitry shows hyperexcitable disturbance in a mouse model of the adult-onset neurodegenerative disease amyotrophic lateral sclerosis. J Neurosci 28:10864-10874.

Van Zundert B, Izaurieta P, Fritz E, Alvarez FJ (2012) Early pathogenesis in the adult-onset neurodegenerative disease amyotrophic lateral sclerosis. J Cell Biochem 113:3301-3312.

van Pelt J, Dityatev AE, Uylings HB (1997) Natural Variability in the number of dendritic segments: model based inferences about branching during neurite outgrowth. J Comp Neurol 387:325-340.

Vinay L, Brocard F, Pflieger JF, Simeoni-alias J, Clarac F (2000) Perinatal development of lumbar motoneurons and their inputs in the rat. Brain Res Bull 53:635-647.

Vinay L, Brocard F, Clarac F, Norreel JC, Pearlstein E, Pflieger JF (2002) Development of posture and locomotion: an interplay of endogenously generated activities and neurotrophic actions by descending pathways. Brain Res Rev 40:118-129.

Vinsant S, Mansfield C, Jimenez-Moreno R, Moore VD, Yoshikawa M, Hampton TG, Prevette D, Caress J, et al. (2013) Characterization of early pathogenesis in the SOD1(G93A) mouse model of ALS: part II, results and discussion. Brain Behavior 3:431-457.

Vucic S, Rothstein JD, Kiernan MC (2014) Advances in treating amyotrophic lateral sclerosis: insights from pathophysiological studies. Trends Neurosci 37:433-442.

Wainger BJ, Kiskinis E, Mellin C, Wiskow O, Han SSW, Sandoe J, Perez NP, Williams LA, et al. (2014) Intrinsic membrane hyperexcitability of ALS patient-derived motor neurons. Cell Rep 10:1-11. 
Williamson TL, Cleveland DW (1999) Slowing of axonal transport is a very early event in the toxicity of ALS linked SOD1 mutants to motor neurons. Nat Neurosci 2:50-56.

Zang DW, Lopes EC, Cheema SS (2005) Loss of synaptophysinpositive boutons on lumbar motor neurons innervating the medial gastrocnemius muscle of the SOD1G93A G1H transgenic mouse model of ALS. J Neurosci Res 79:694-699. https://doi.org/ 10.1002/inr. 20379 .

(Received 23 June 2020, Accepted 31 January 2021)

(Available online $x x x x$ ) 